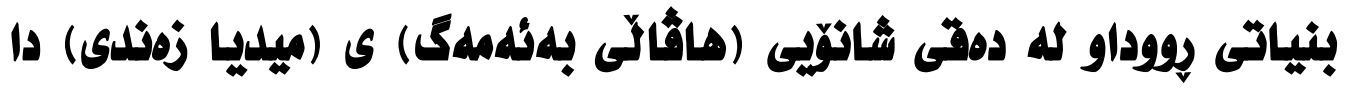

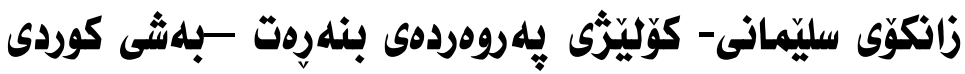

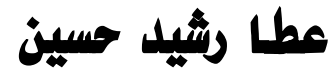

\section{: :}

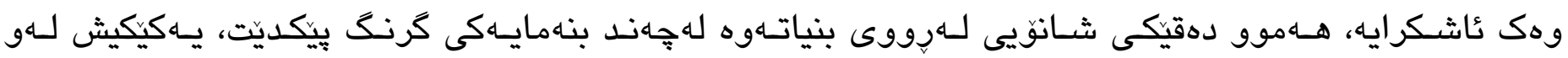

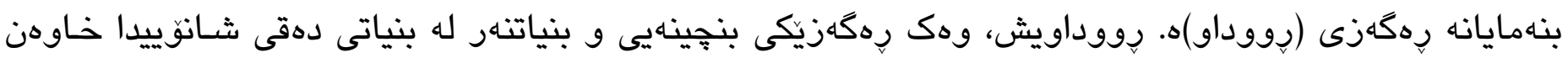

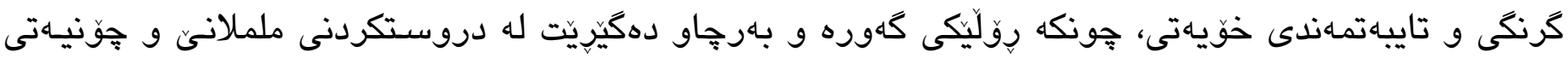
دارشتنى كه سيتى كارهكتهرهكاندا.

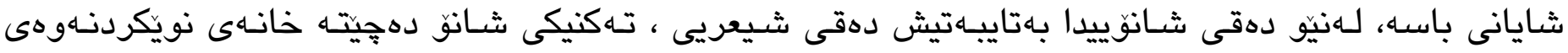

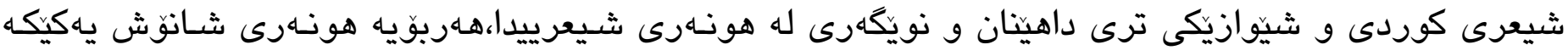

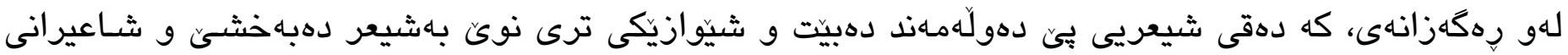

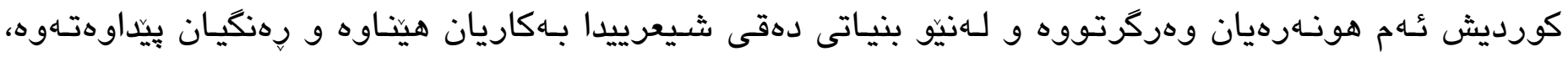

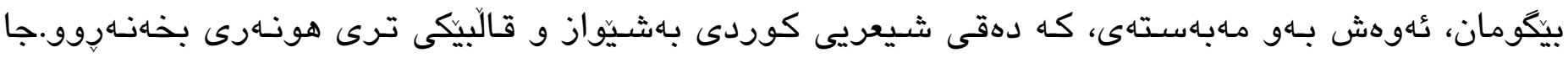

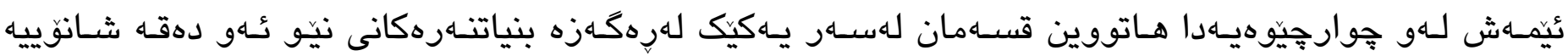
شييعرييه كردووه، كه رهكهزى رِوروداوهن.

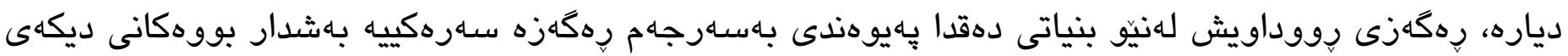

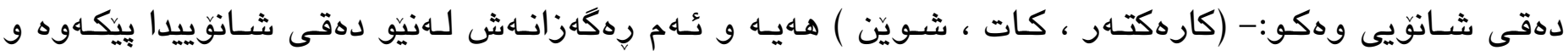

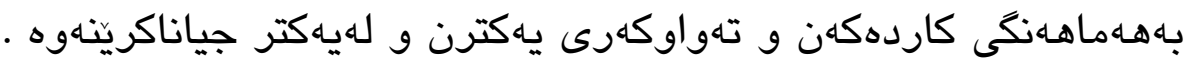

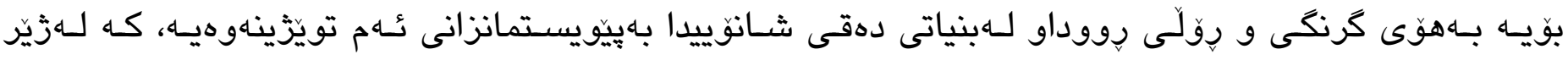

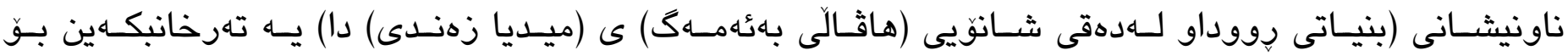

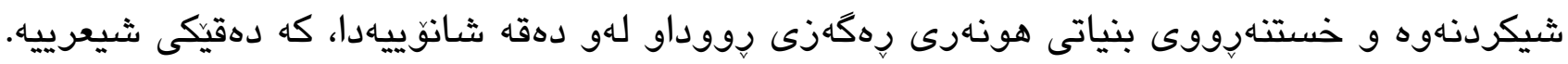

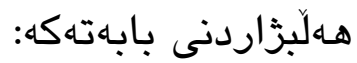

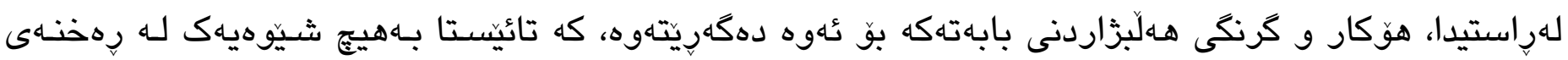

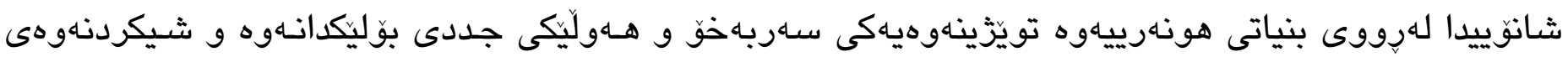

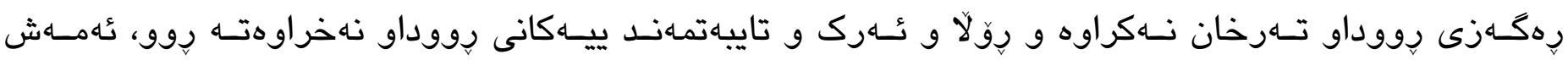

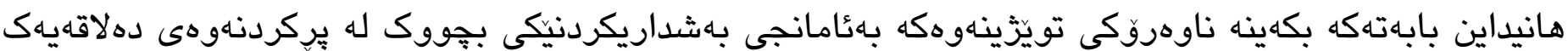

له رهخنهى شـانوييدا.

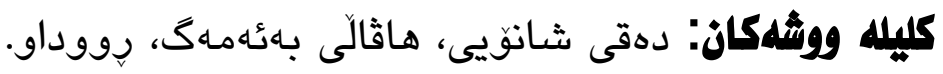




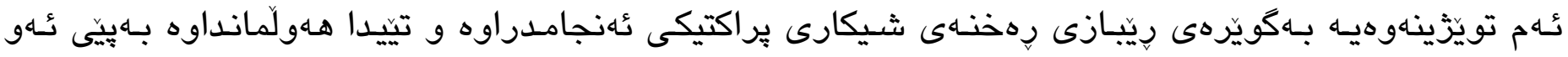

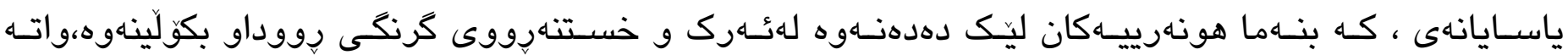

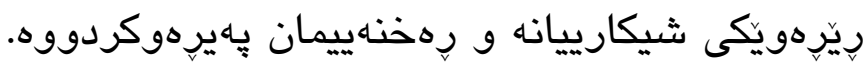

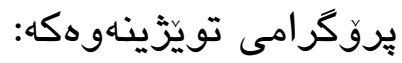

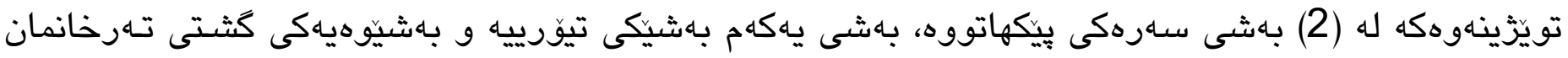

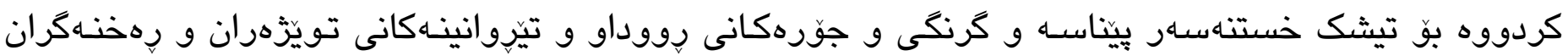

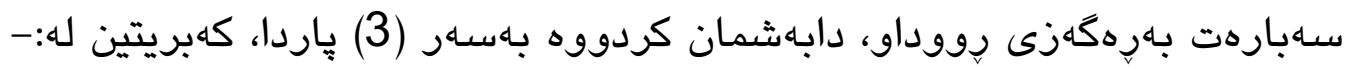

01

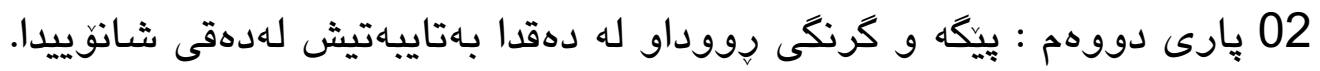

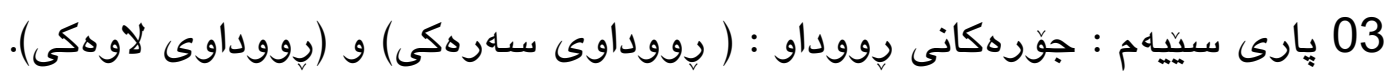

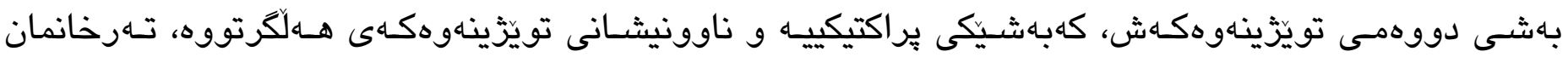

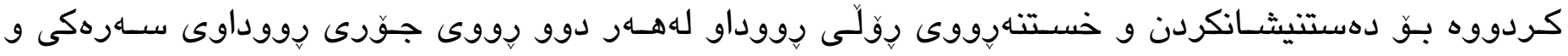

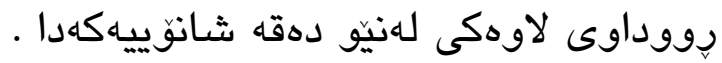

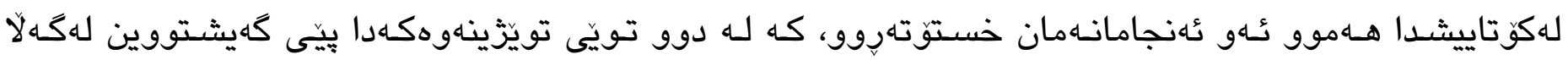

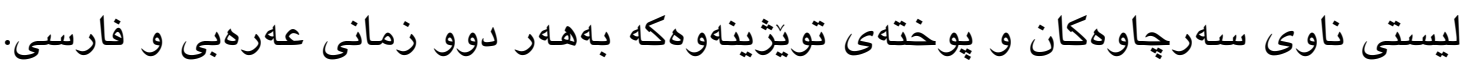




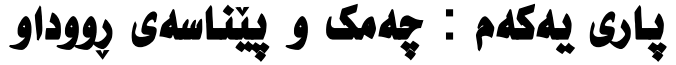

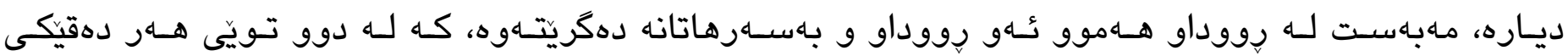

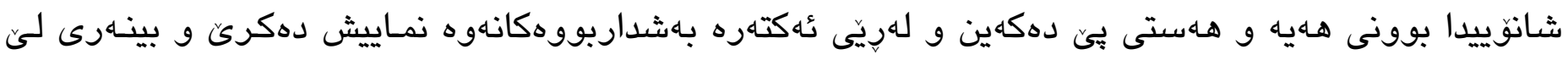

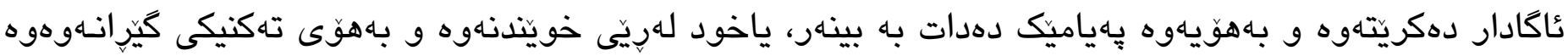

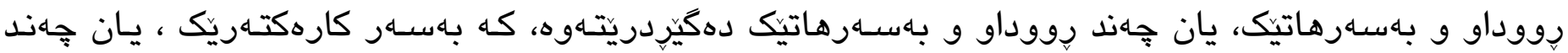
كارهكتهريكدا هاتووه.

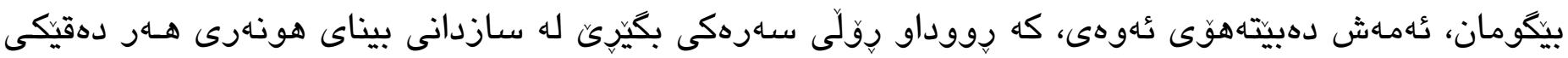

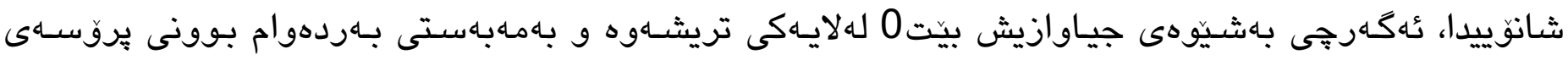

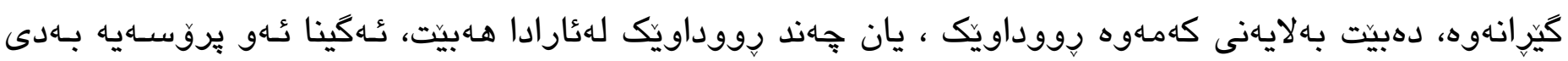

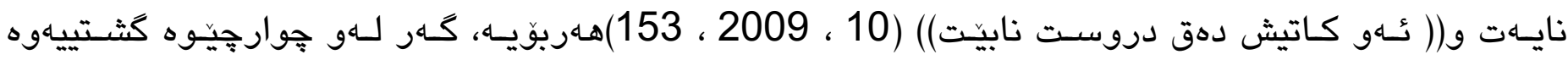

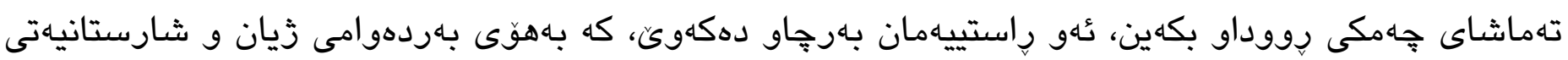

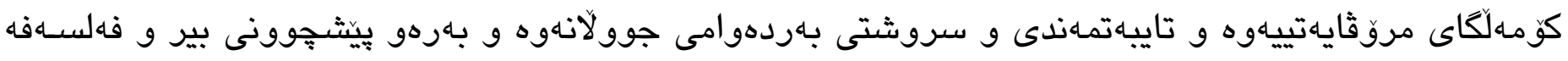

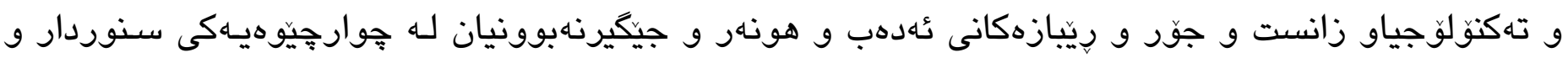

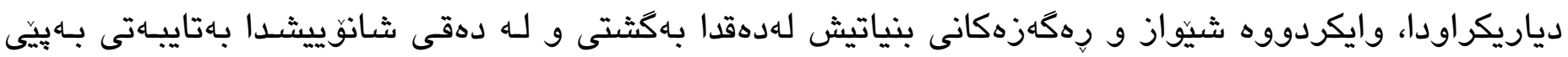

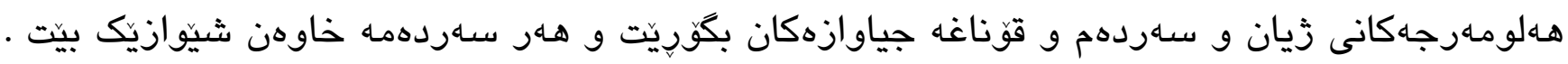

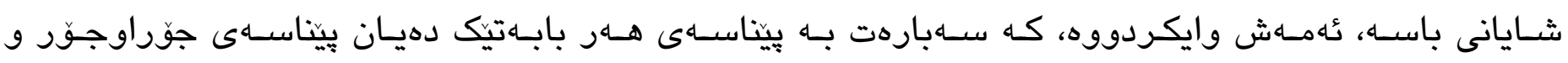

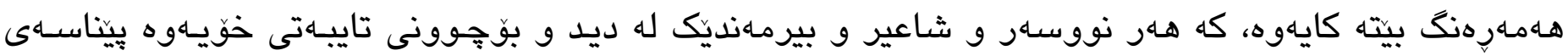

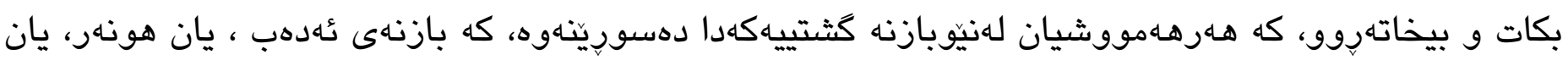

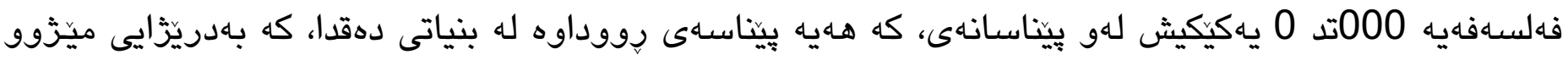

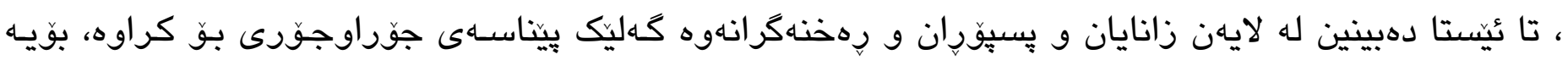

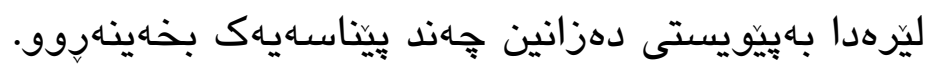

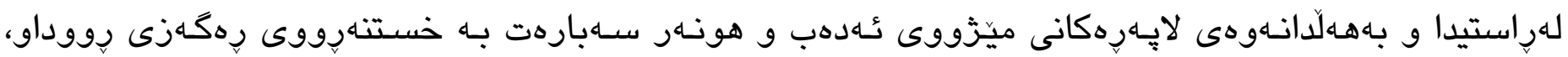

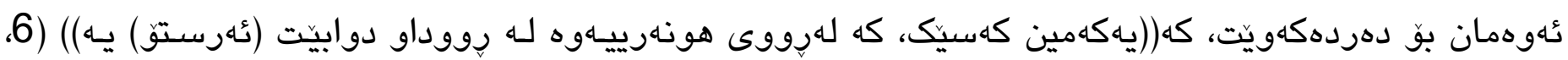

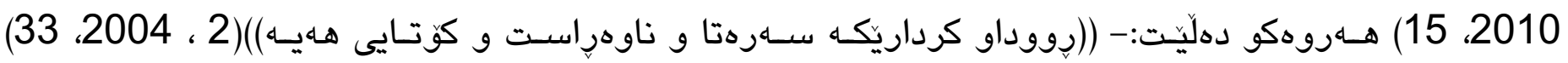

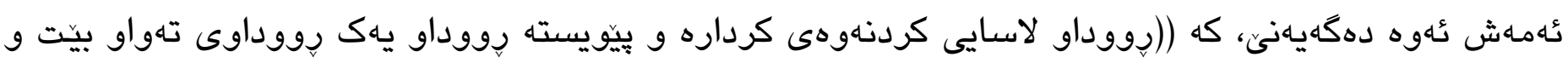

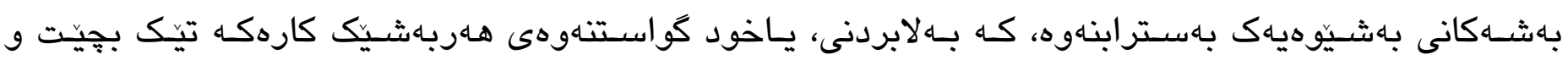

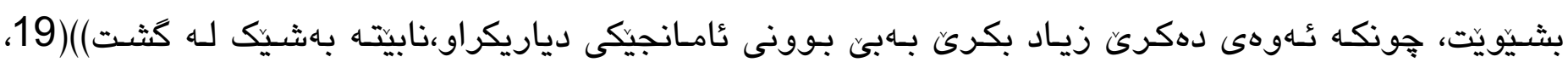

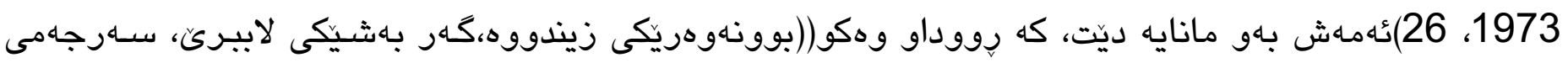

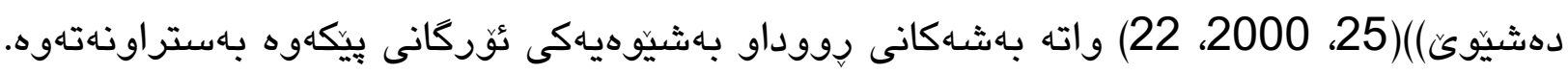

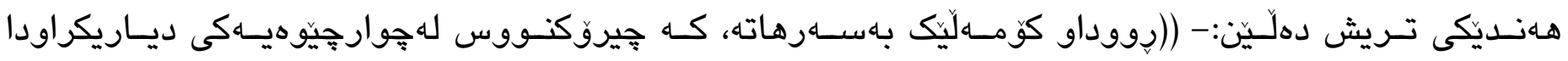

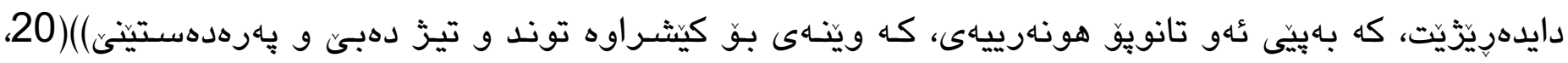

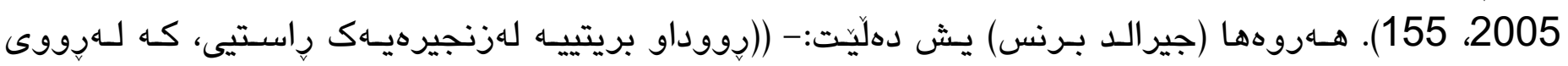

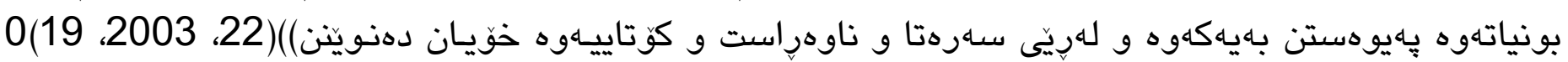




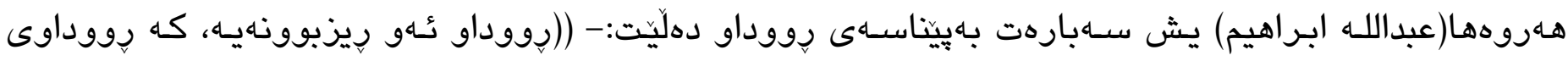

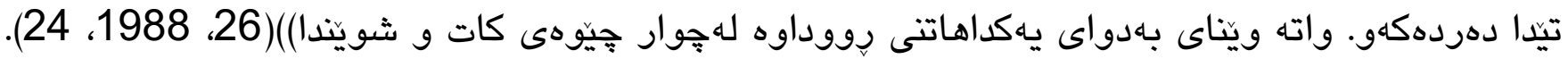

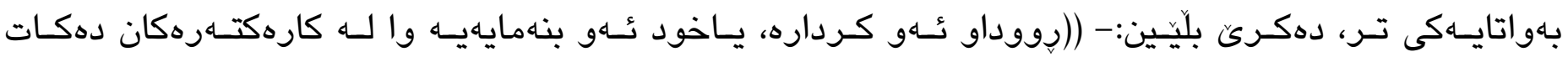

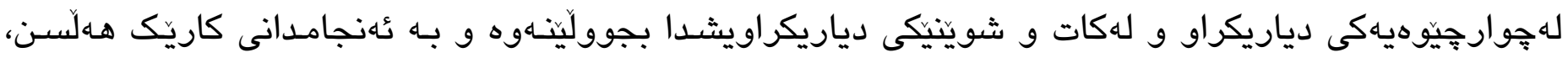

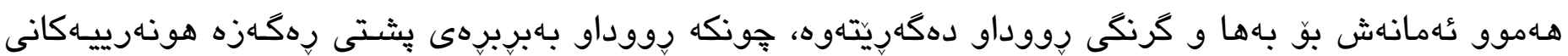

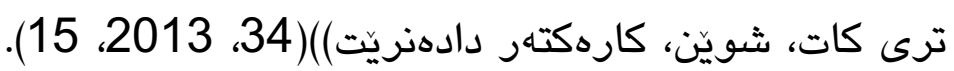

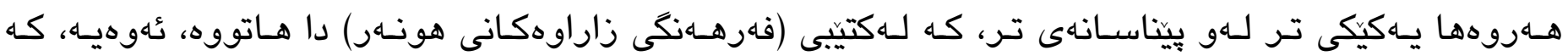

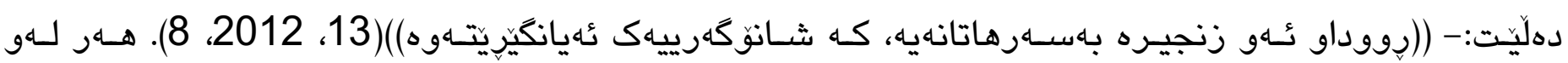

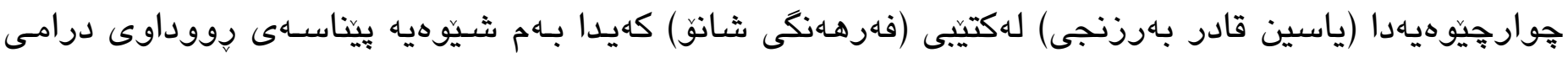

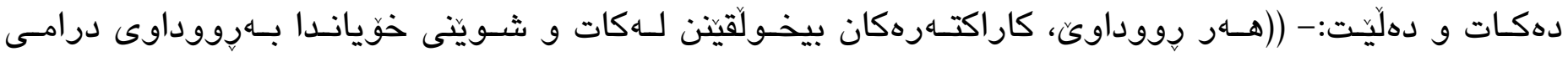

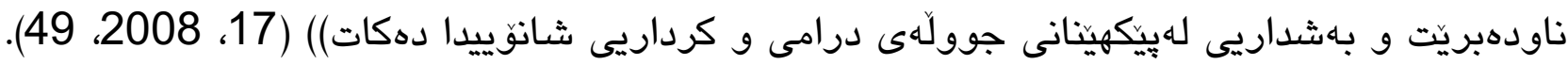

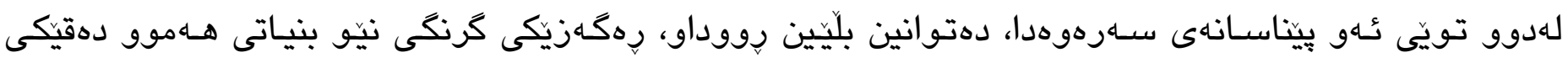

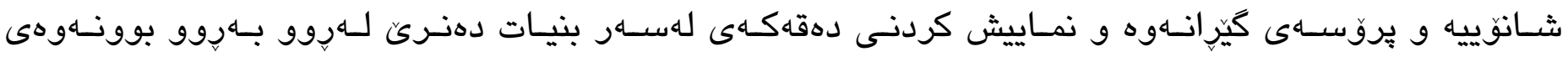

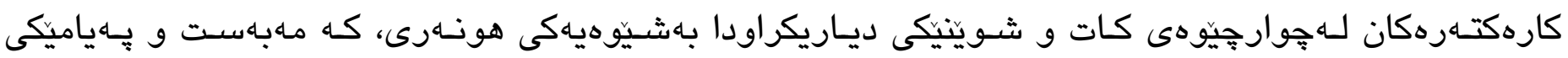
تايبهت و دياريكراوى له يشتهوهيه .

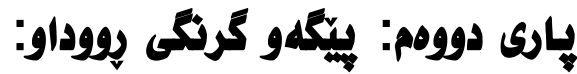

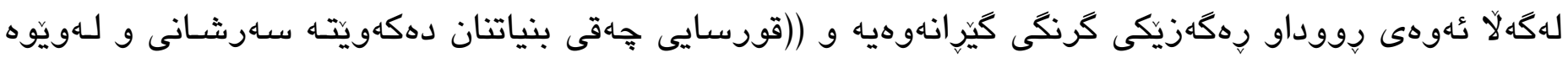

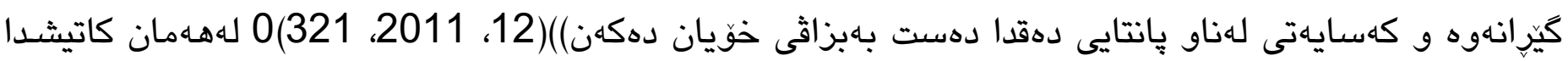

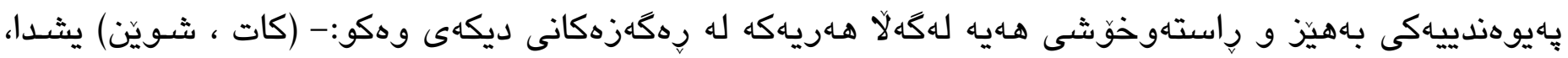

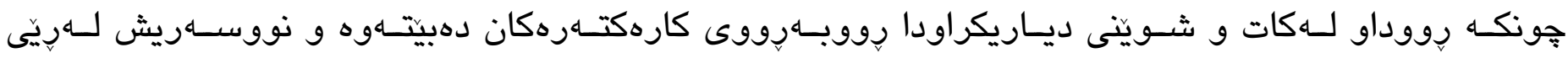

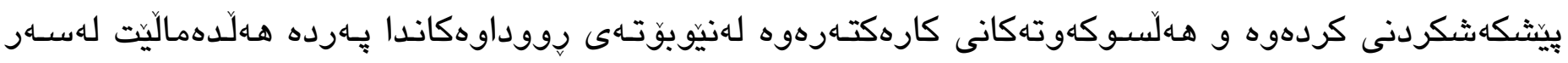

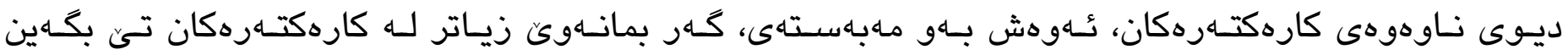

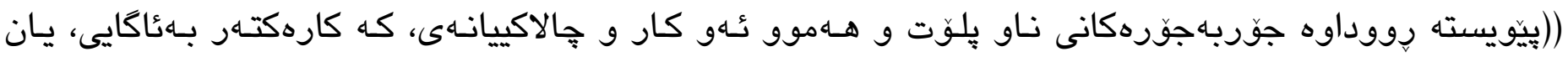

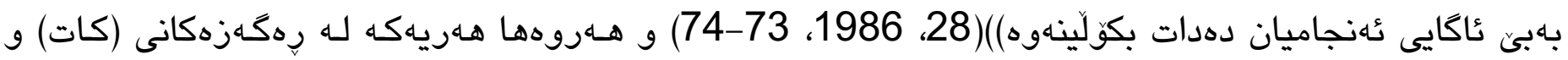

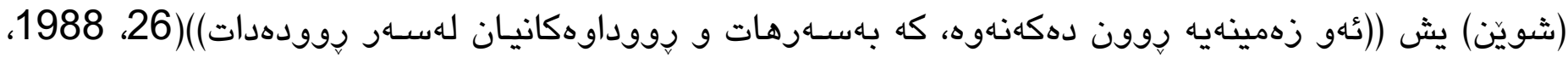

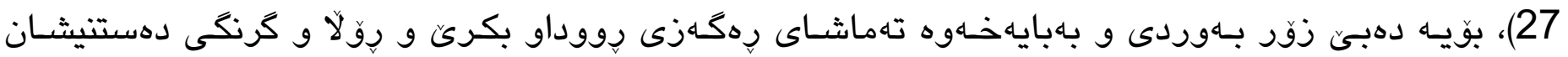
بكرىیى.

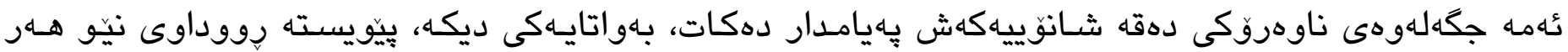

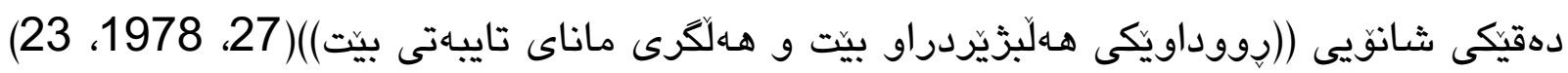

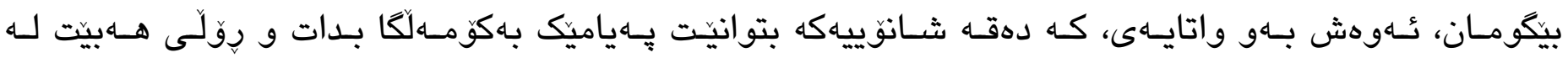

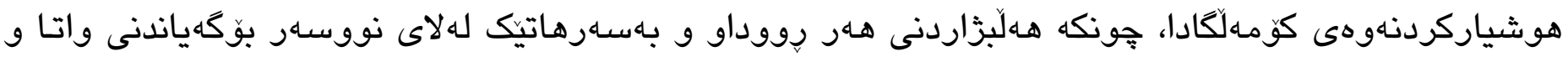

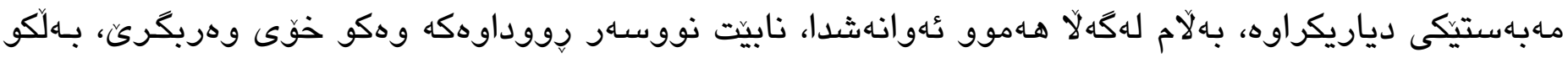




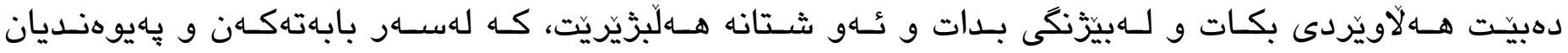
بهابابهتهكهوه هـهيـ.

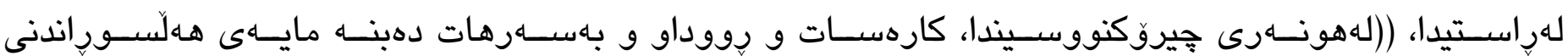
كهرهستهى سـرهكى و نيشانهى زيندوويتى و جموجوولى بحى راوهستانى زيان لهدهقهكها()(4، 1988،

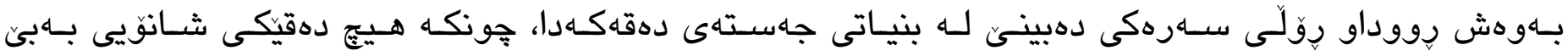

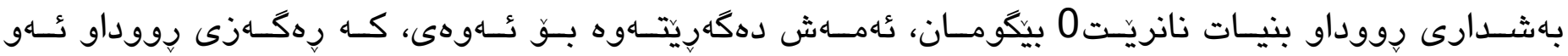

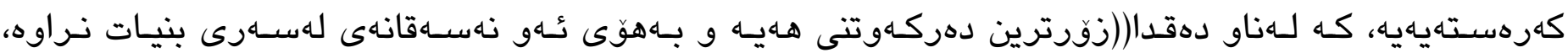

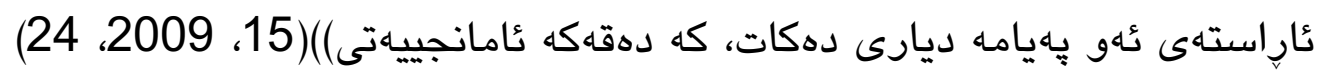

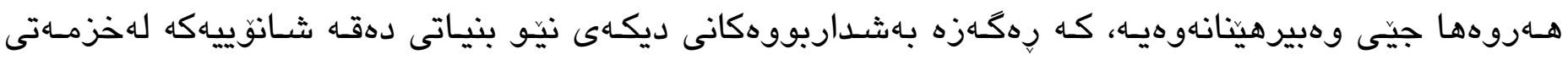

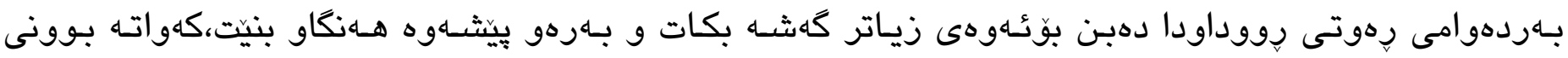

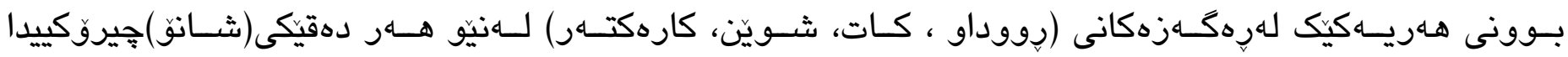

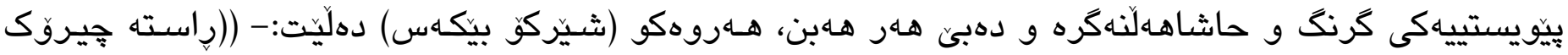

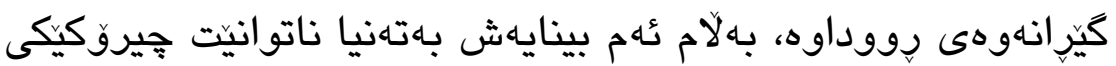

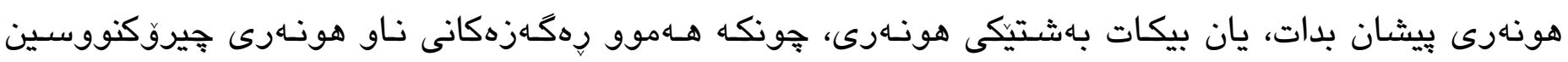

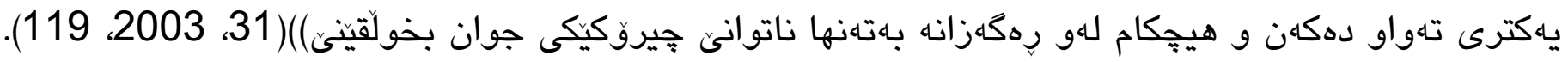

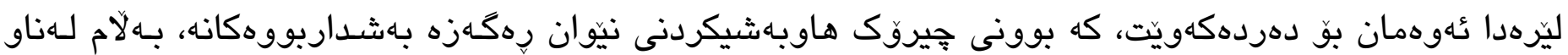

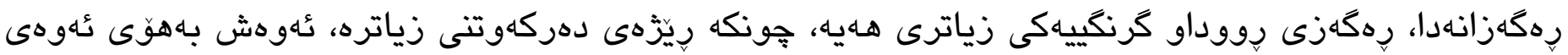

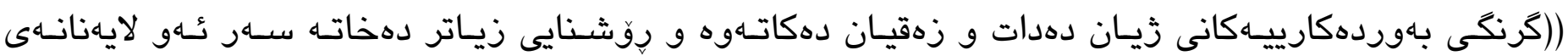

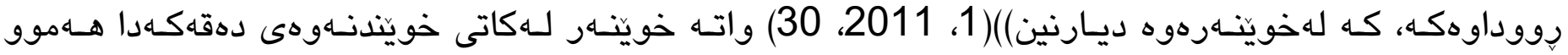

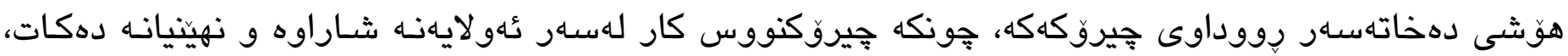

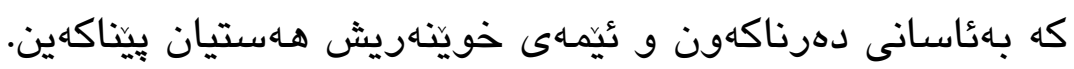

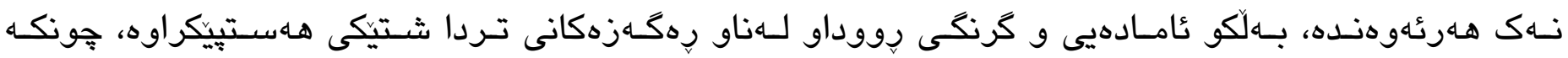

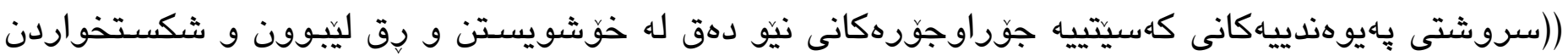

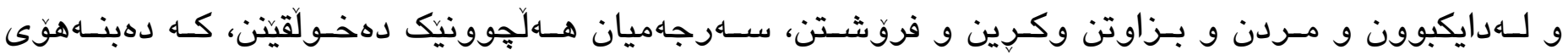

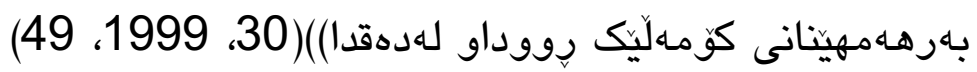

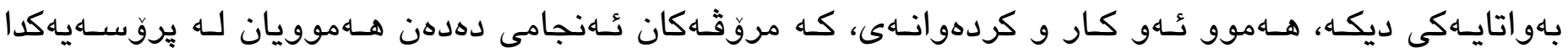

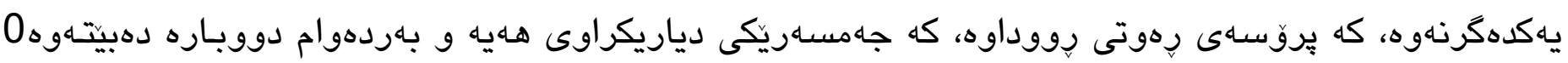

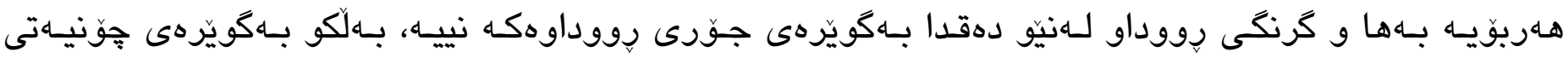

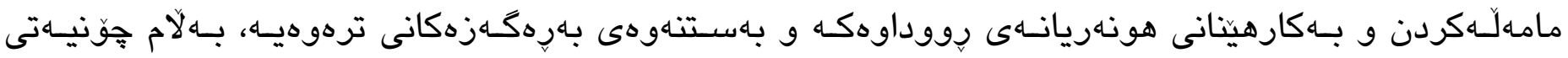

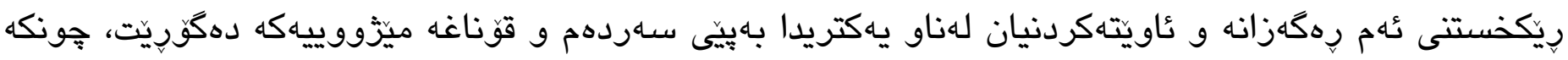

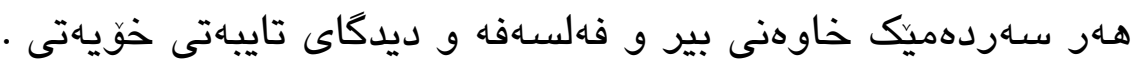

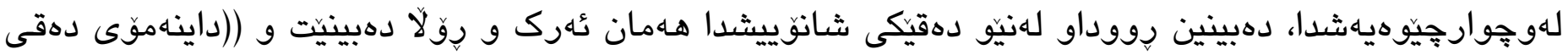

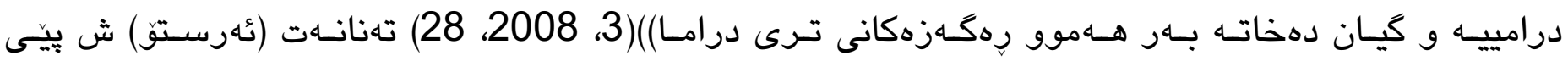

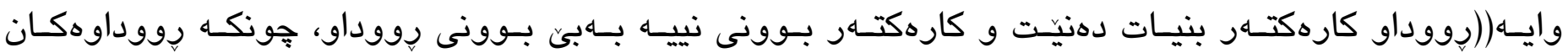

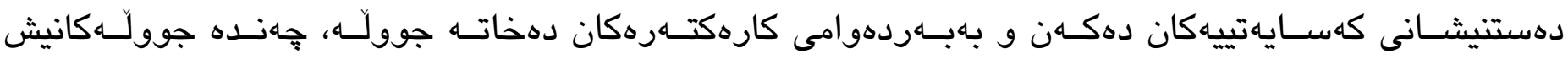




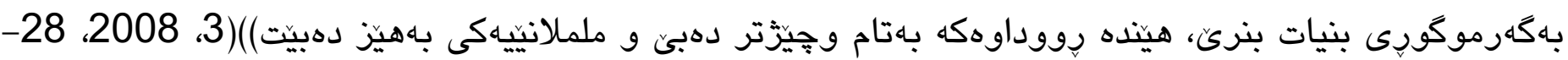

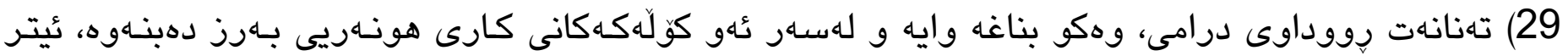

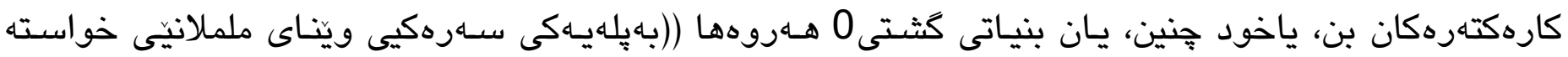

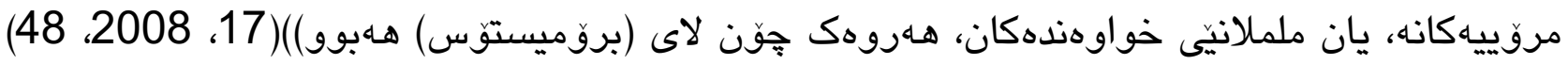

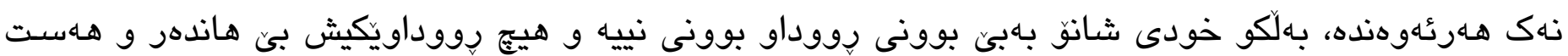

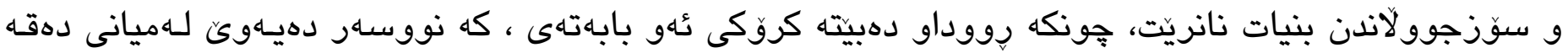

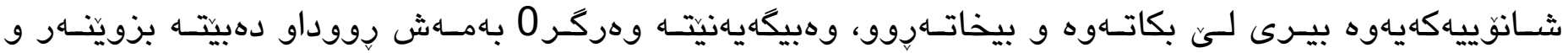

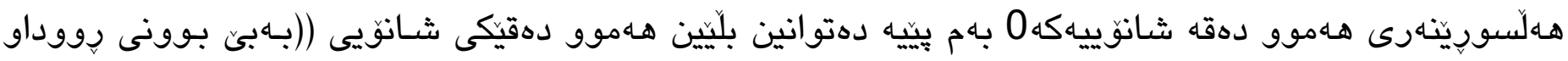

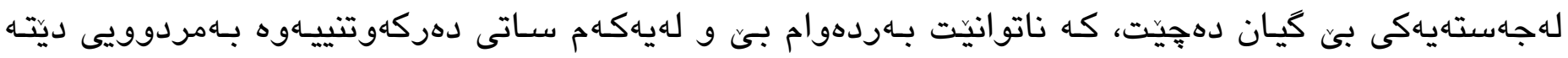

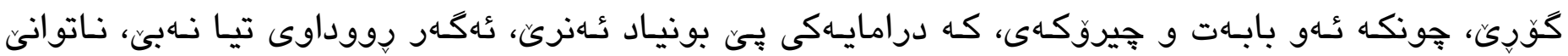

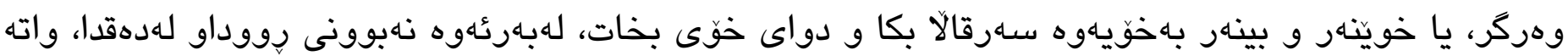

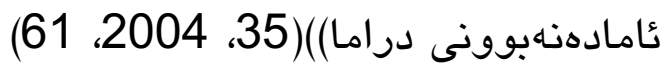

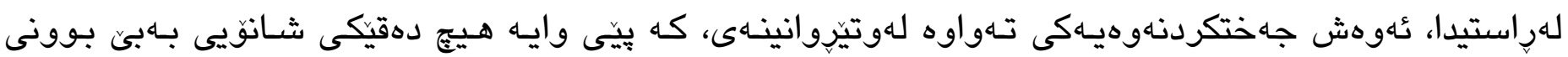

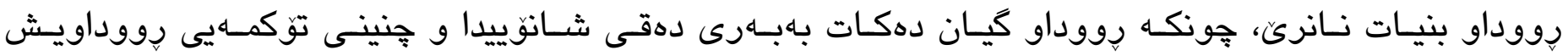

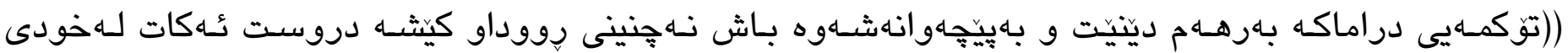

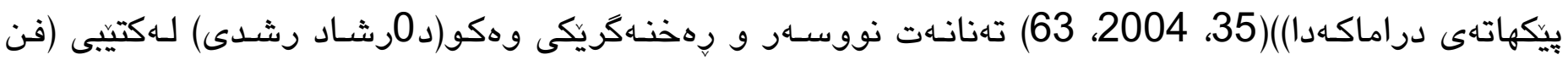

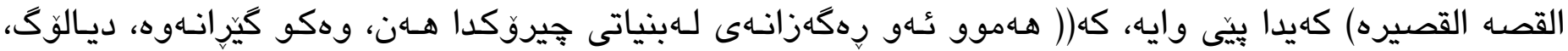

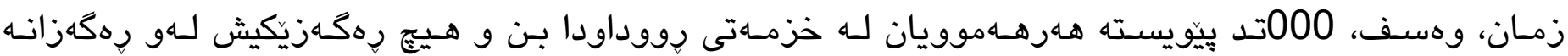

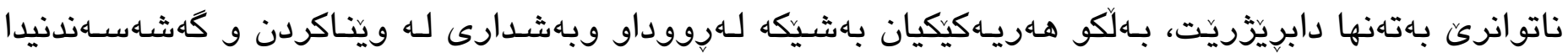

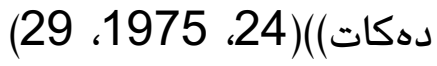

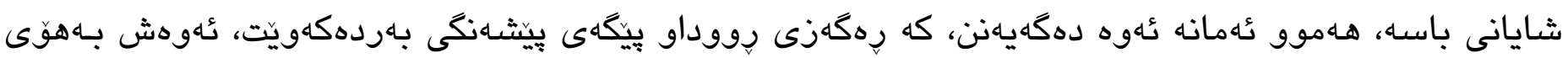

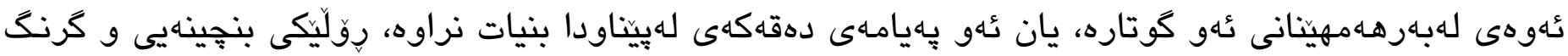

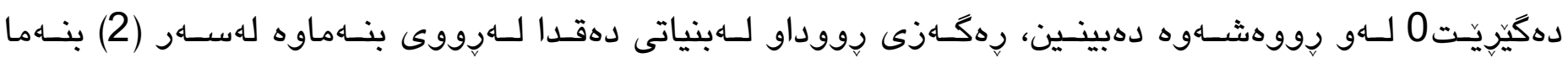

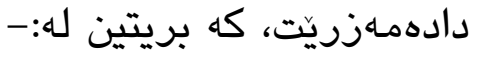
(جابهابتى دهق بيكيك دههينيتي)

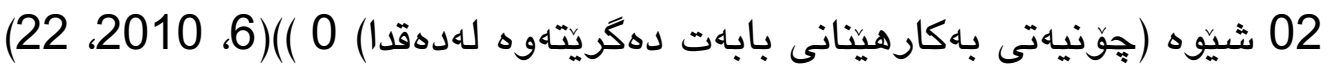

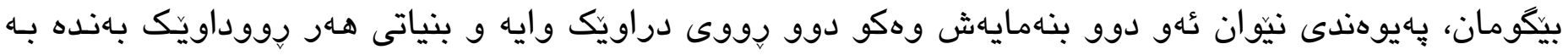

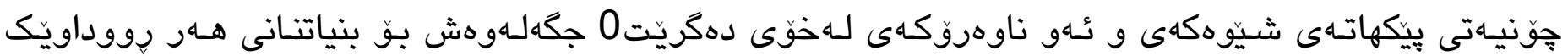

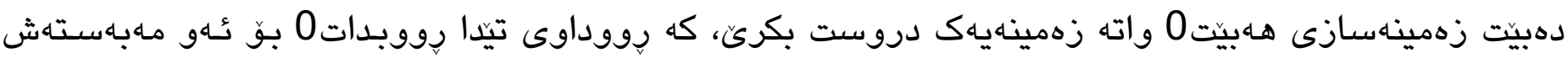

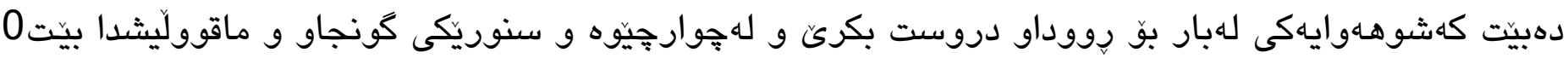

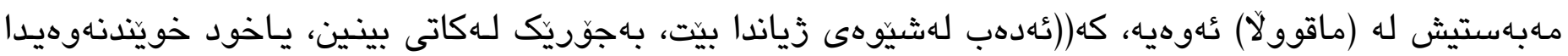

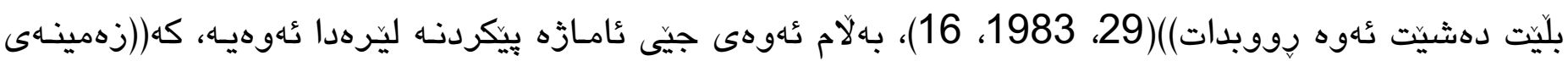

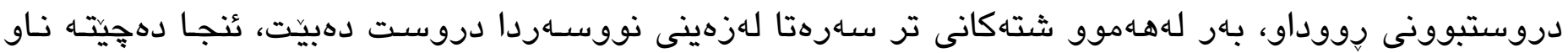

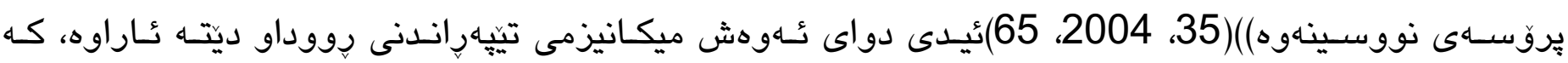

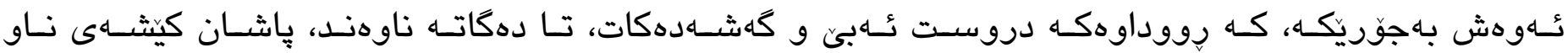


رِووداوهكه قهيران دروست دهكات و بهردهوام دهبيت لههـلكثشان و دهروات، تا دهكاته ترويكى قهيرانهكه، ئيدى

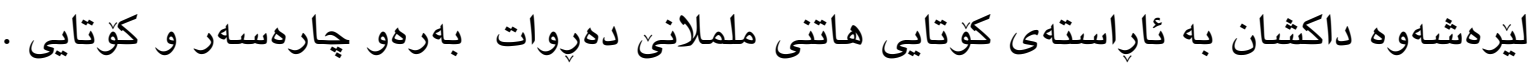

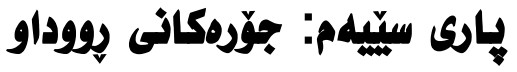

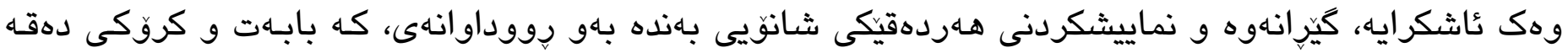

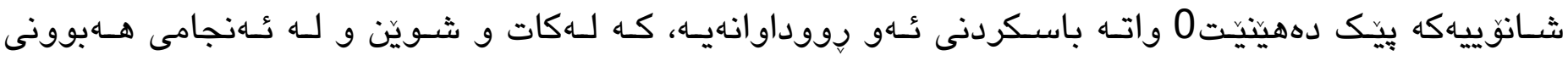
كارهكتهرهكانى نيّو دهقهكها ديتّهكايهوه

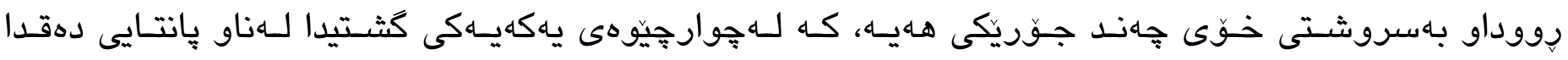

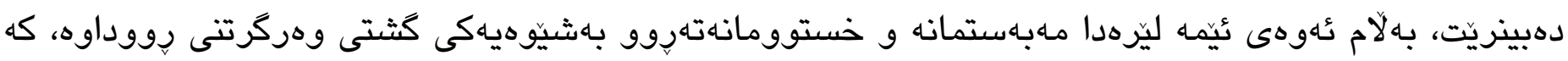

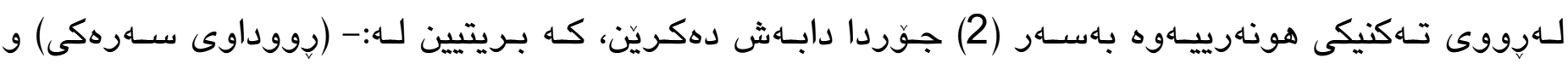

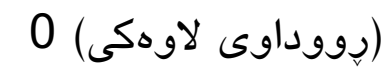
: 01

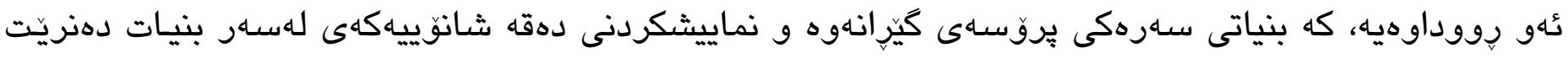

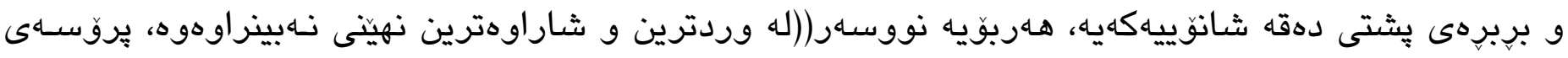

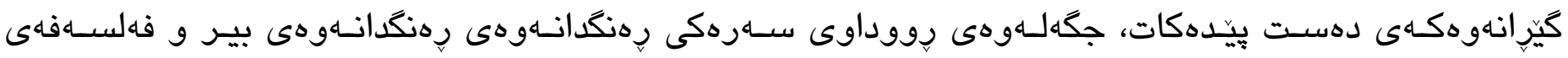

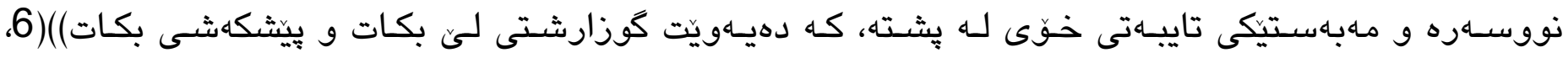

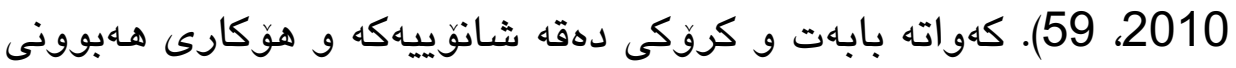

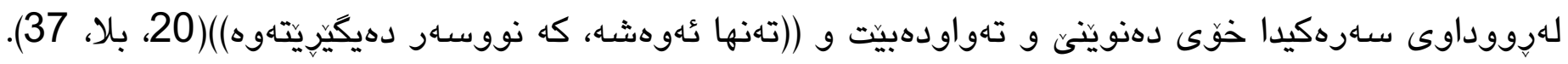

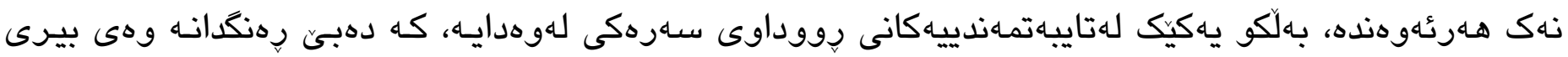

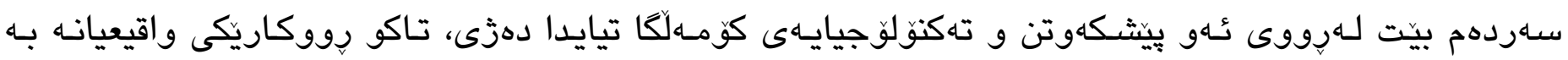

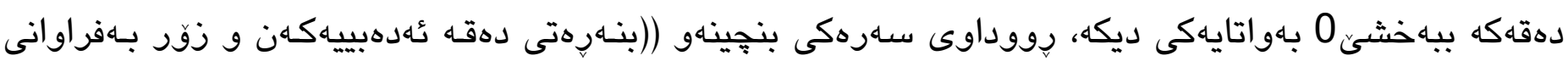

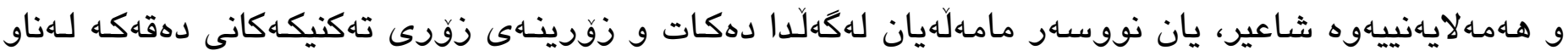

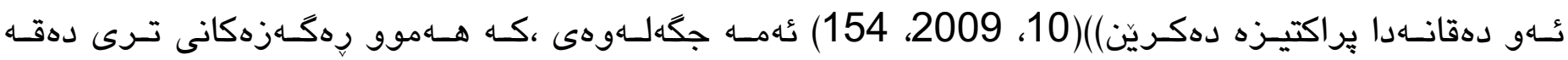

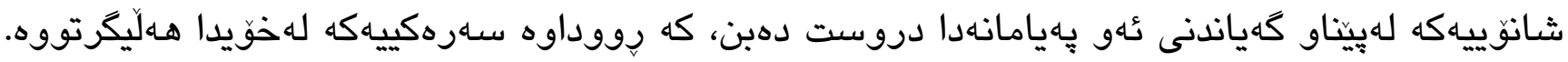

\section{: 02}

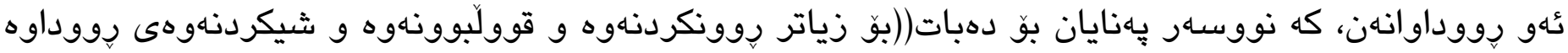

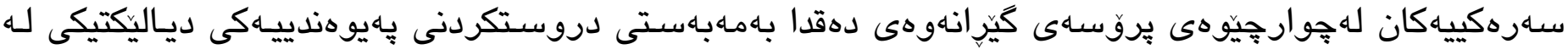

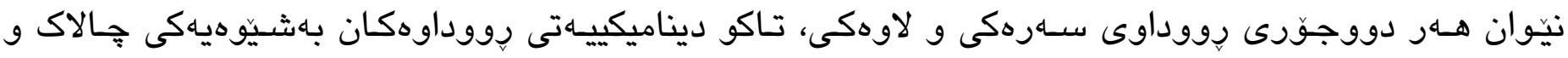

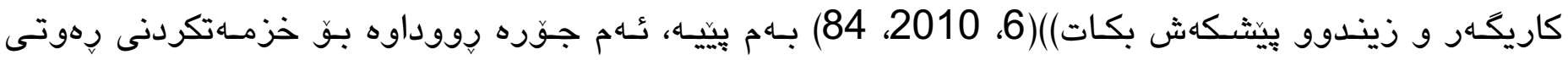

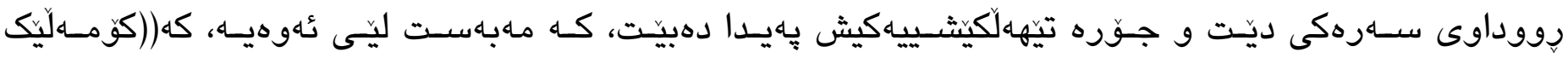




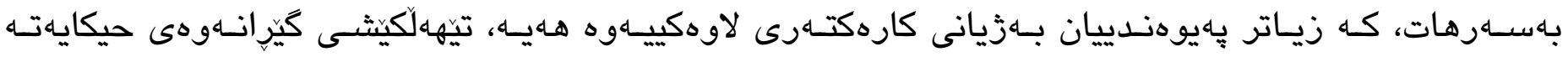

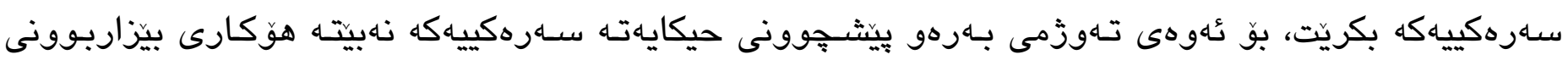

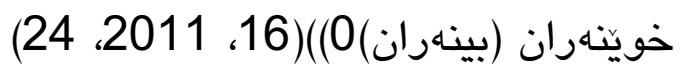

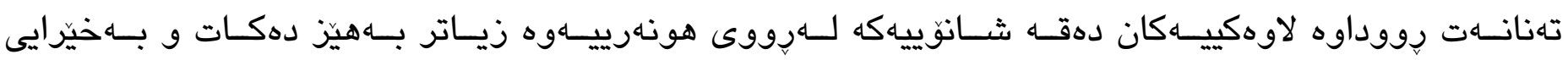

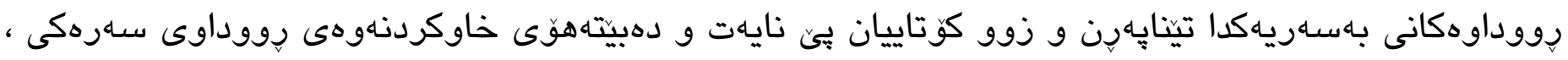

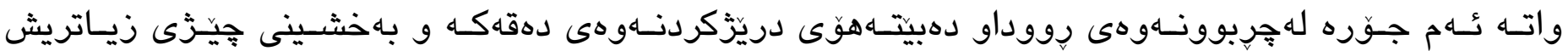

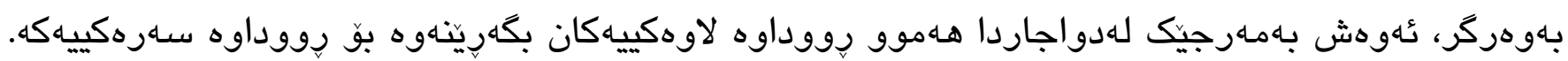

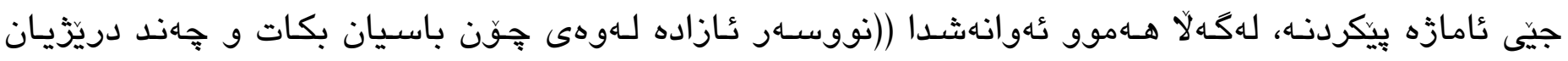

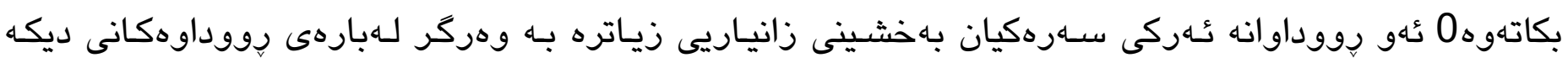

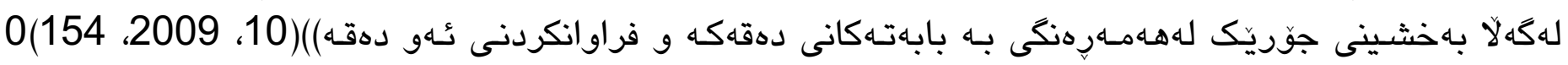

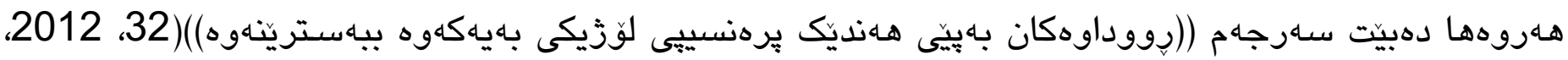

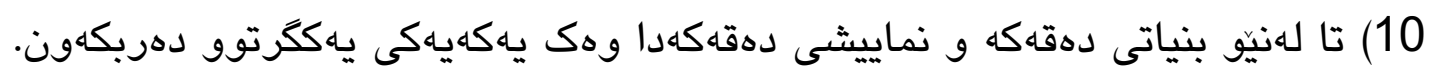

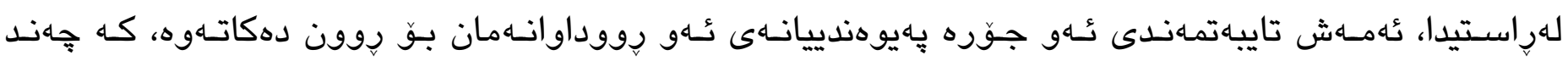

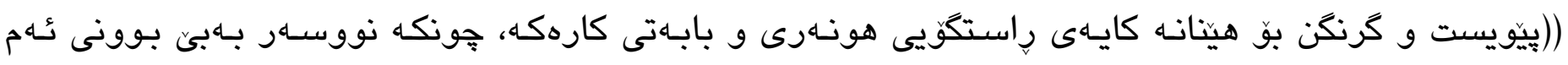

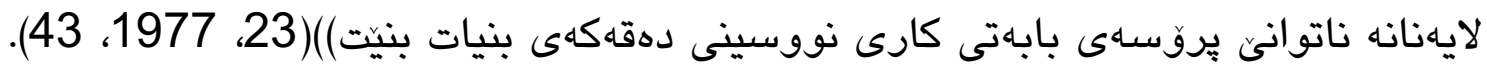

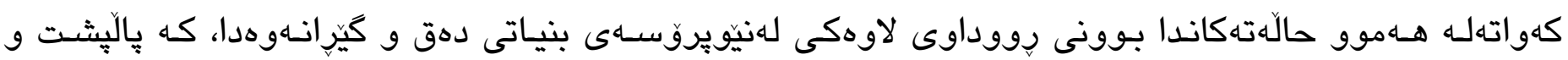

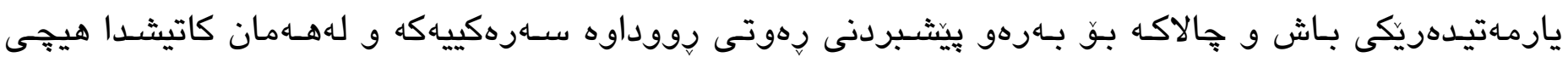

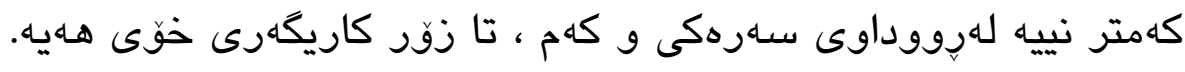




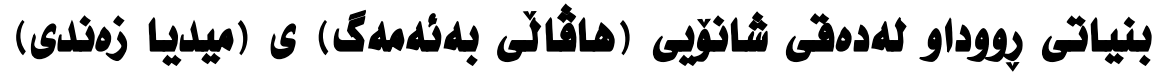

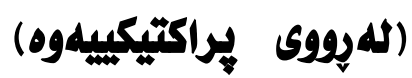

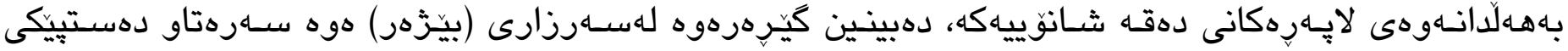

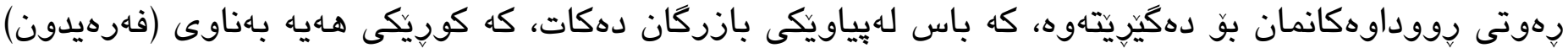

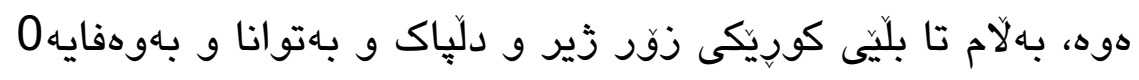

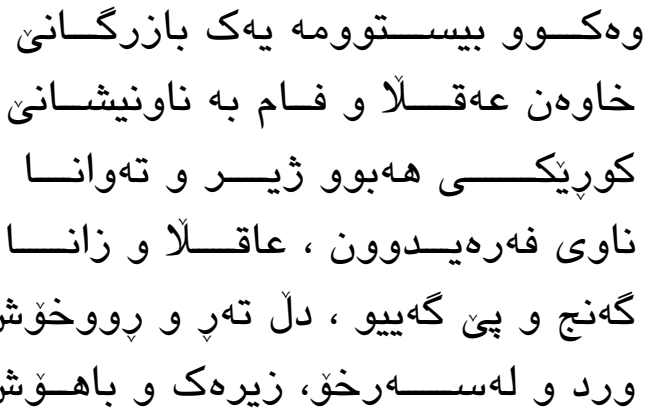

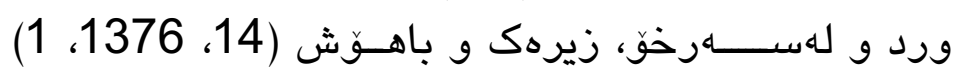

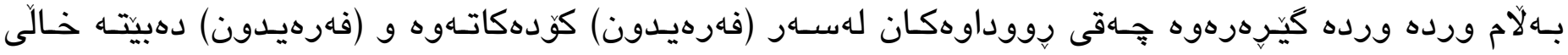

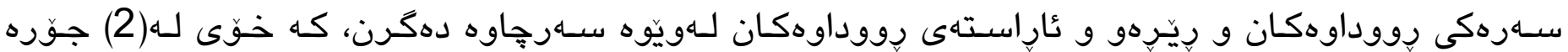

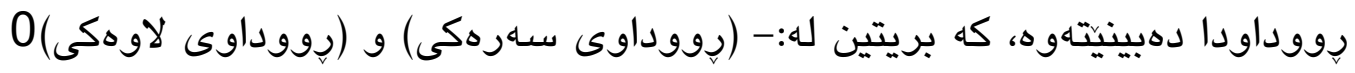

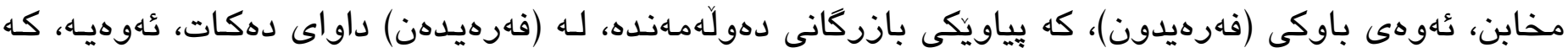

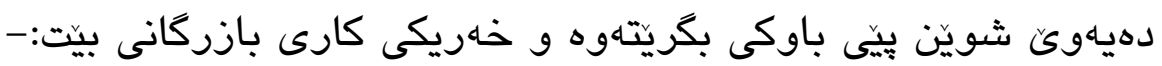

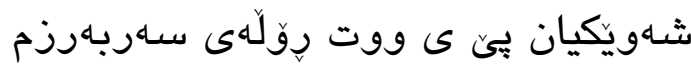

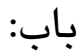

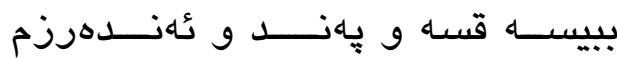

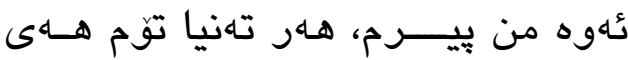

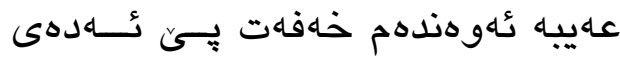

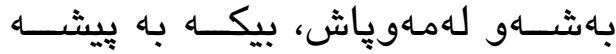

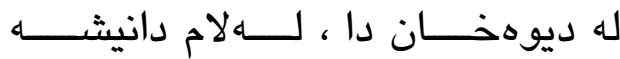

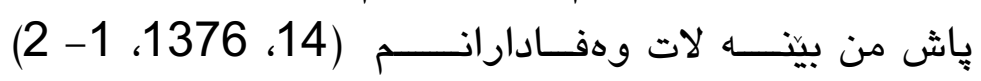

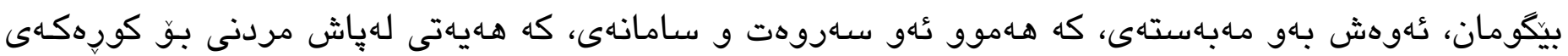

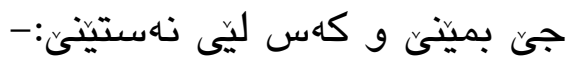

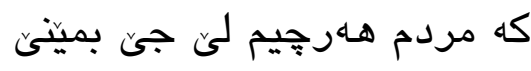

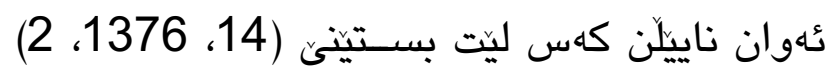

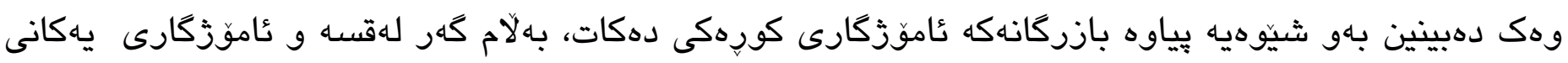

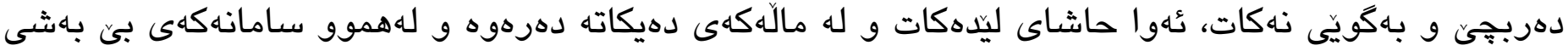

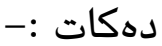

$$
\text { تُهر للهردهوهى خوّت واز نههينتى }
$$

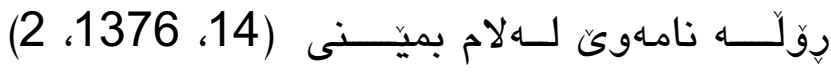


بهلاّم وهك دهردهكهويت، ثاراستهكان بهو شيّوهيه نييه، كه باوكى (فهرهيدون) خوازياريستى، بهالكو (فهرديدون)

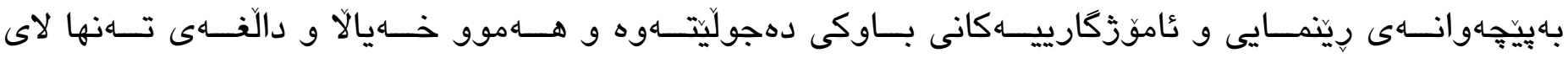

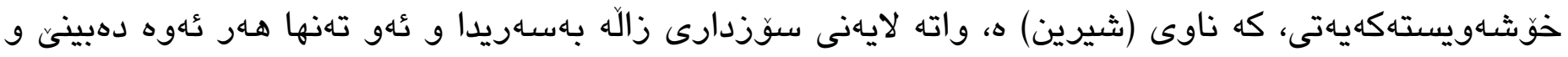
هيجى تر:-

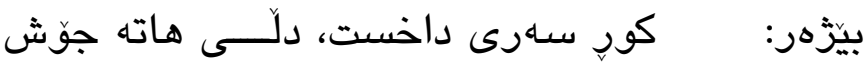

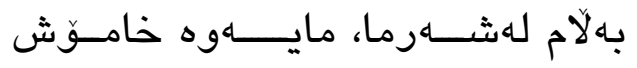

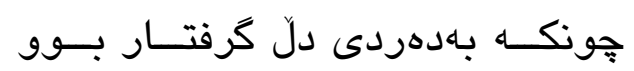

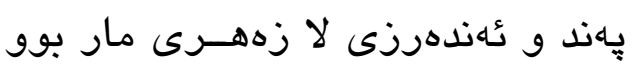

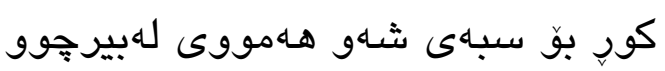

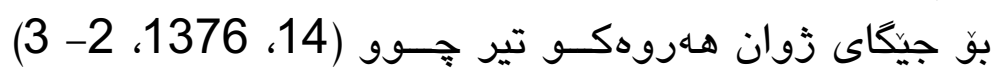

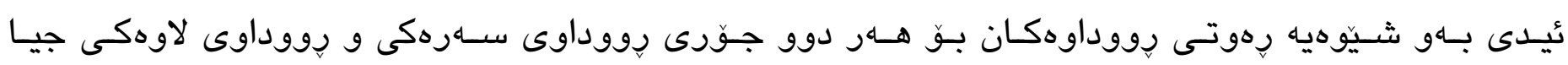
دهبيتهوه

\section{: 01}

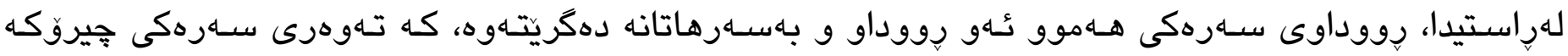

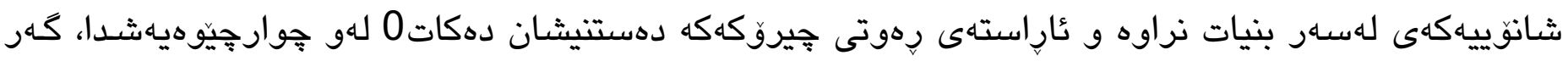

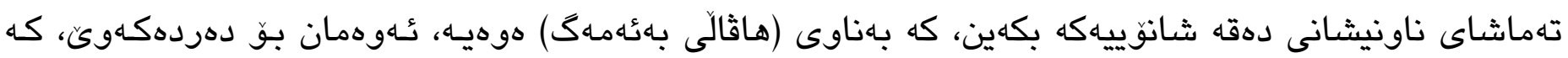

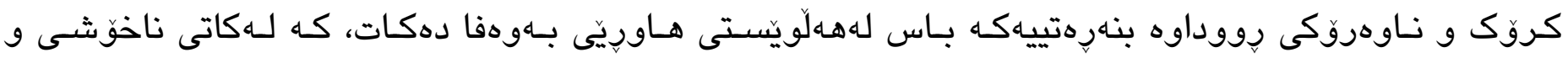

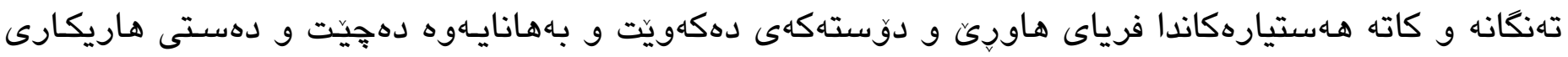

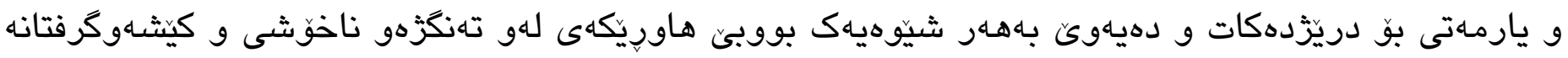

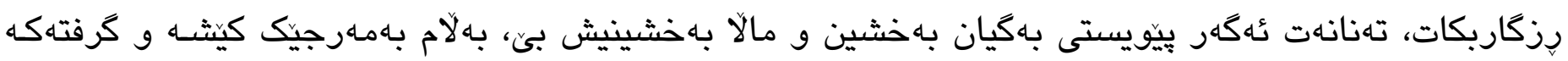

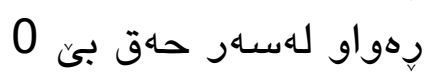

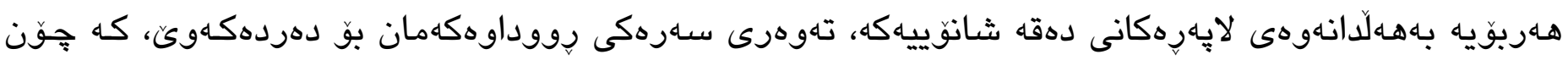

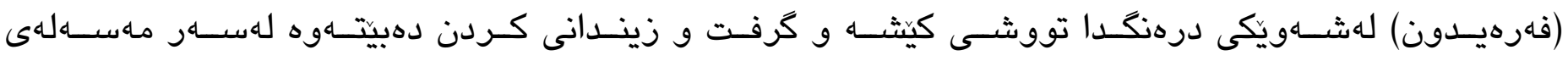

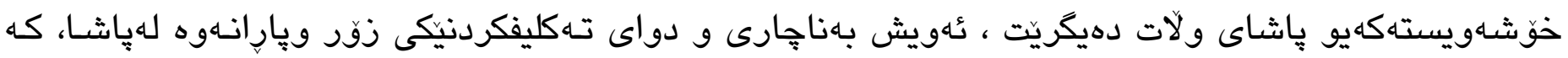

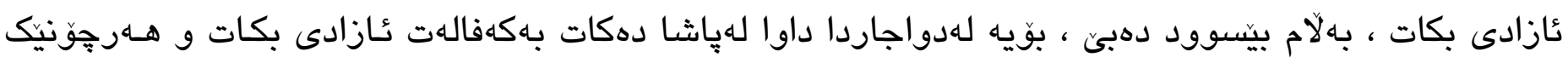

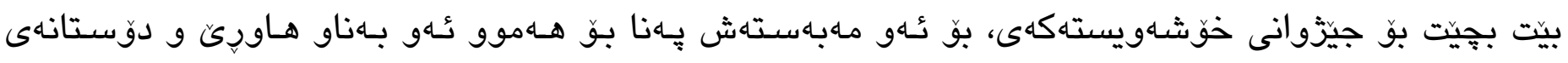

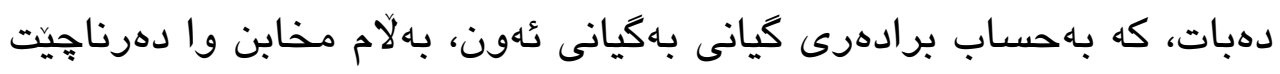

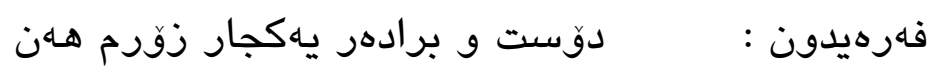

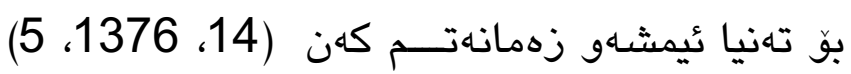

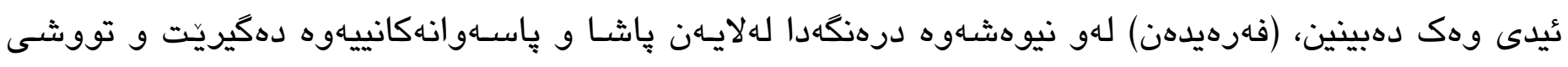

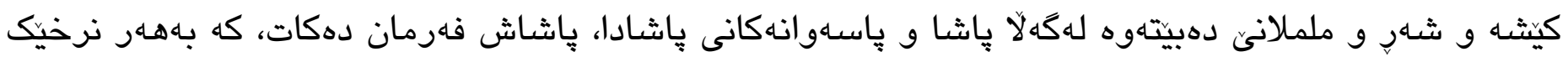

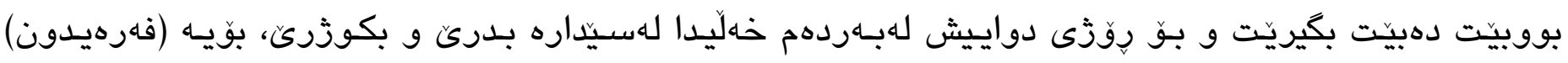

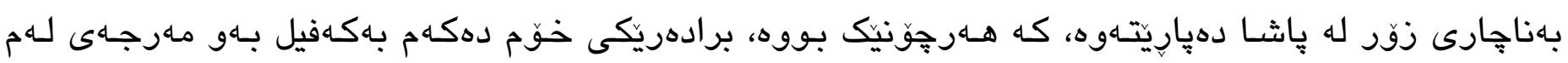

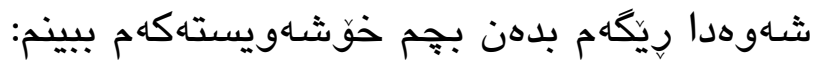

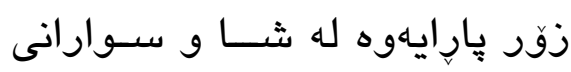


كَهيشته كَهردوون ناله و فوغانى شا زوّ بهزهيسى بينّ دا هاتسهوه

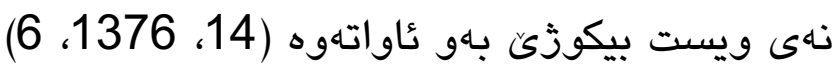

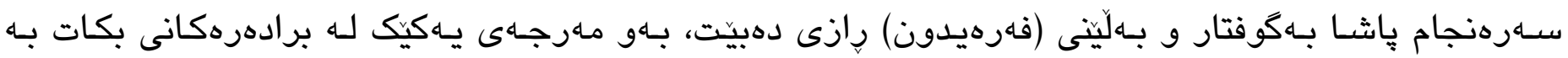

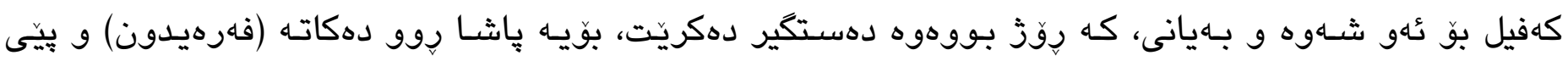

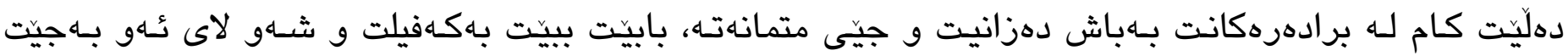
ده دهيّلين:

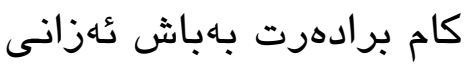

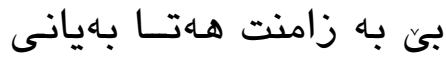

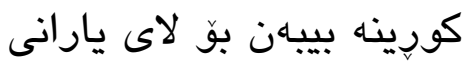

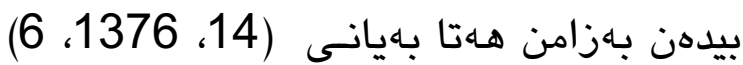

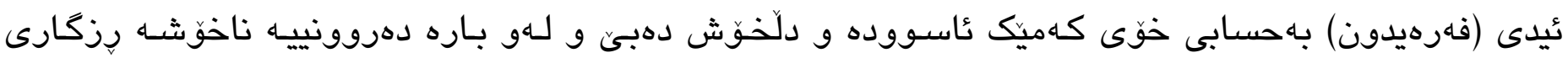

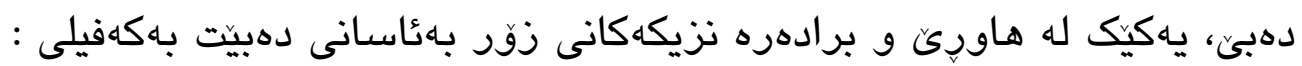

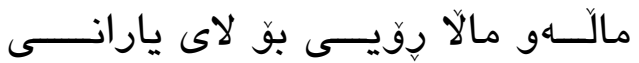

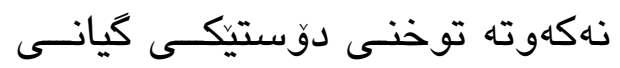

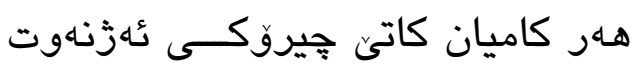

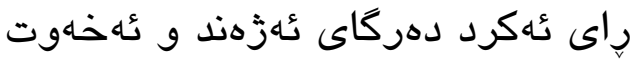

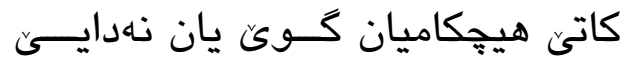

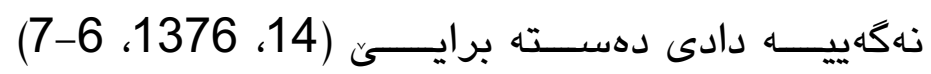

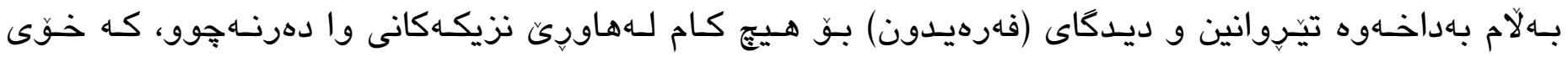

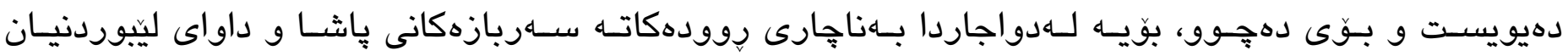

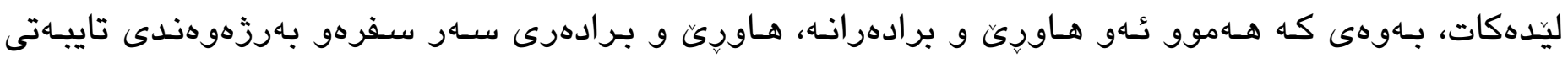

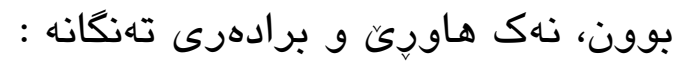

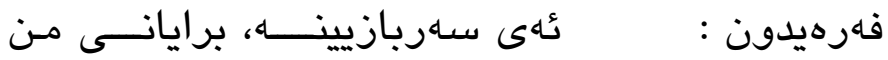

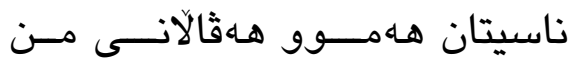

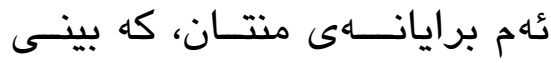

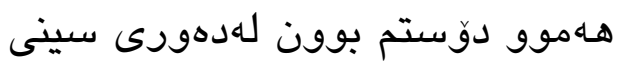

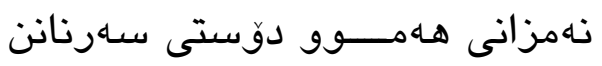

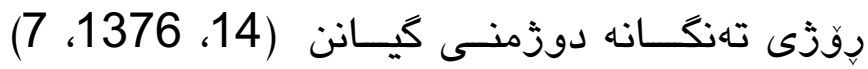

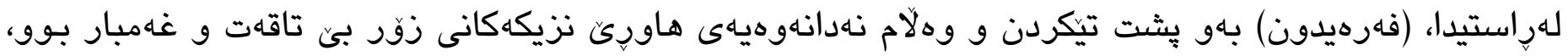

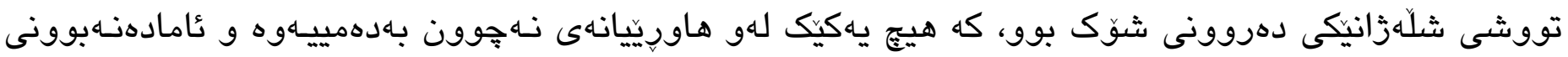

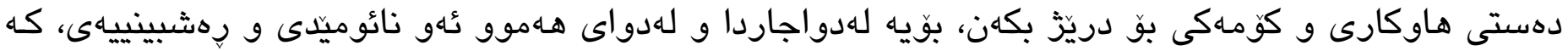

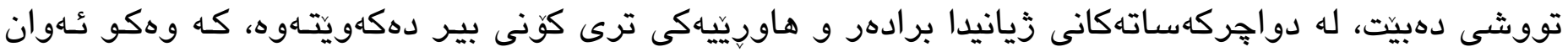

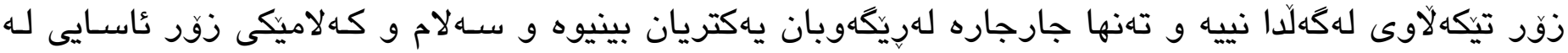

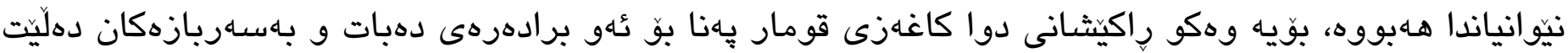




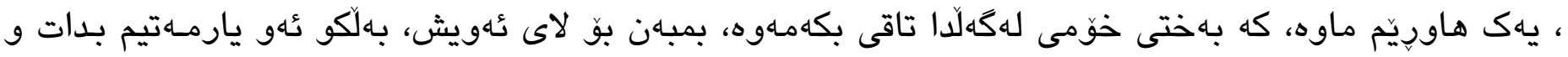

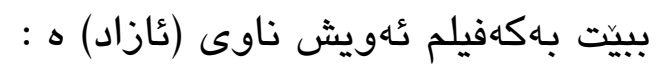

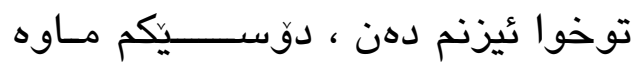

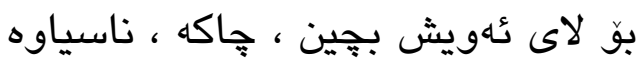

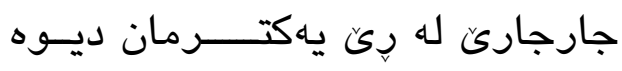

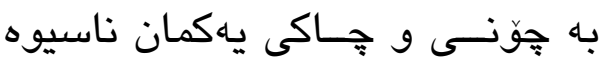

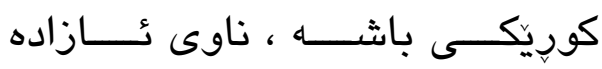

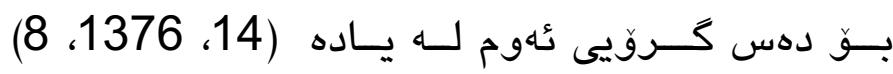

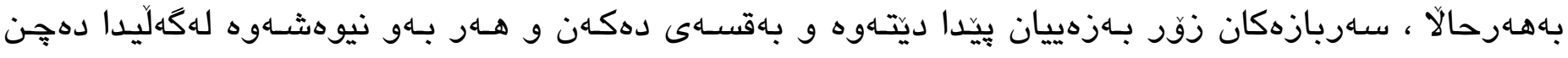

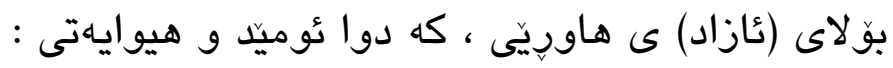

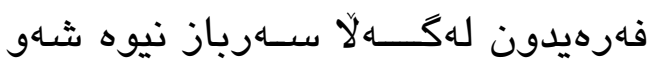

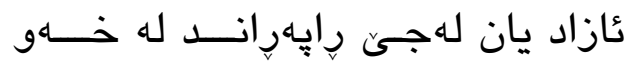

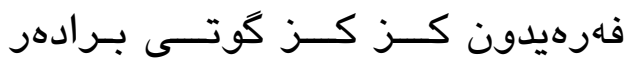

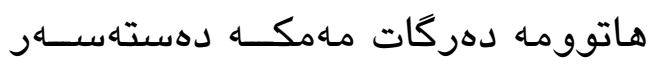

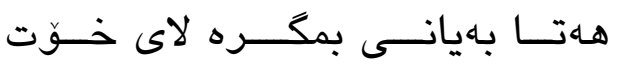

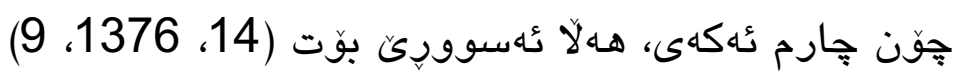

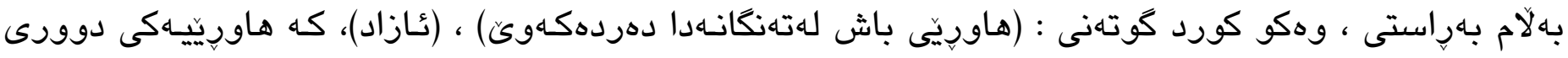

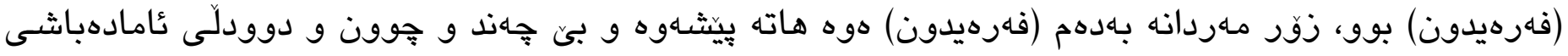

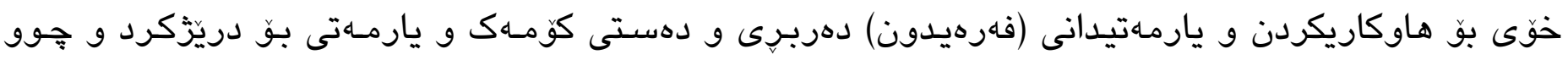

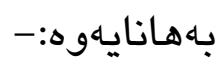

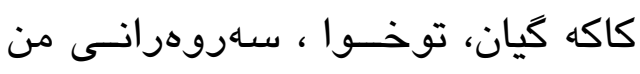

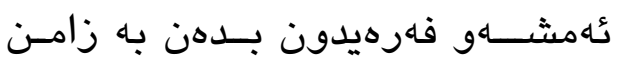

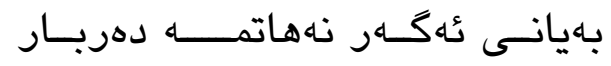

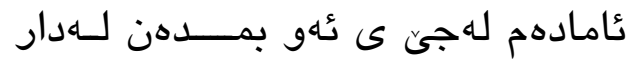

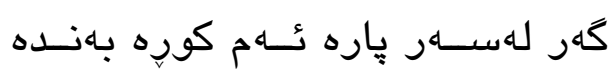

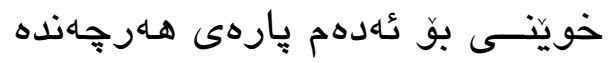

$$
\begin{aligned}
& \text { فهرهيدون ! هـاستى خوّم ئهنيمها رِيّت }
\end{aligned}
$$

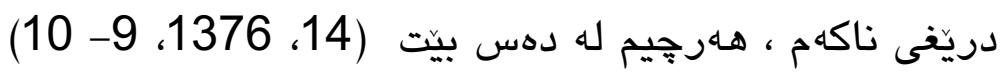

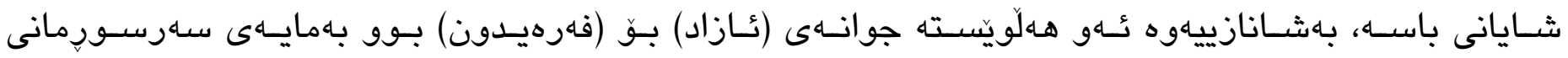

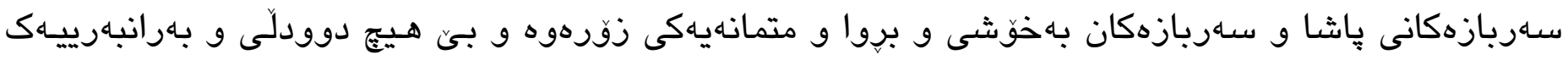

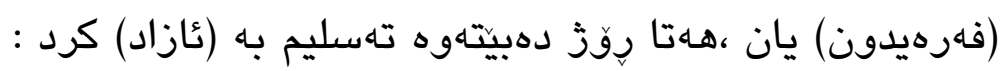

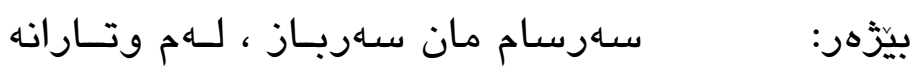

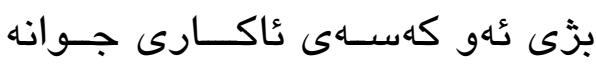

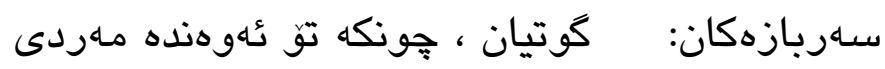

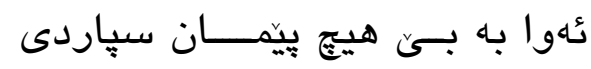




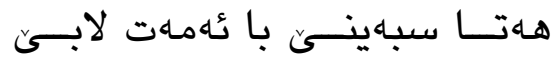

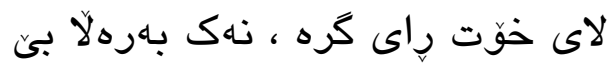

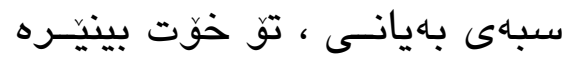

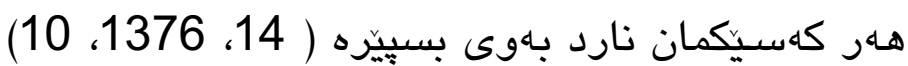

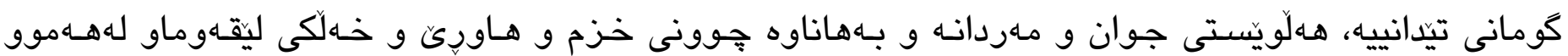

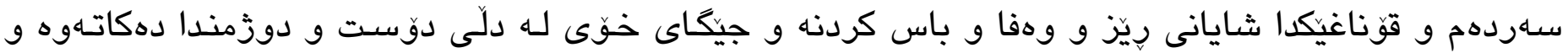

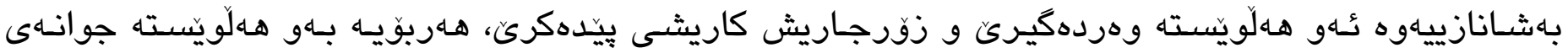

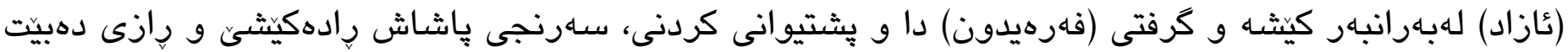

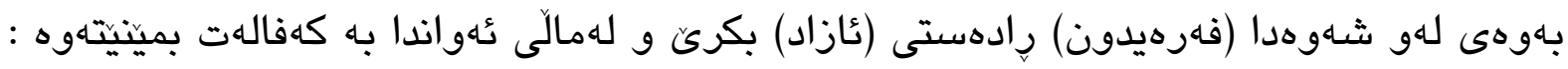

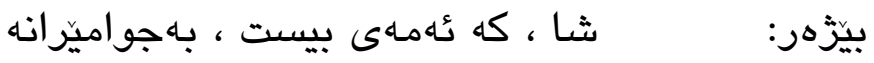
زوو فهرهيدونى تُهسيارد بـهو جوانه

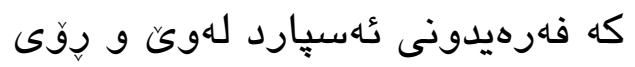

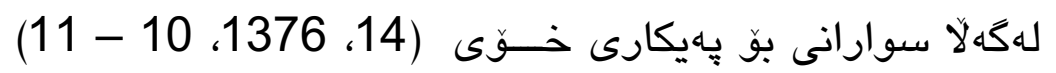

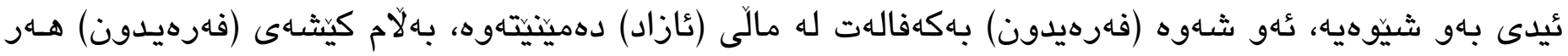

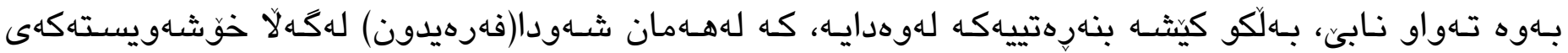

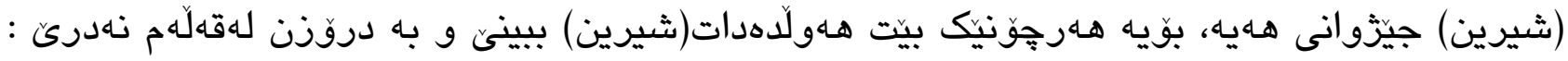

$$
\begin{aligned}
& \text { كاتــي ئازاد نووست ، فهرهيدون هـهـا }
\end{aligned}
$$

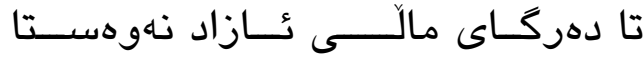

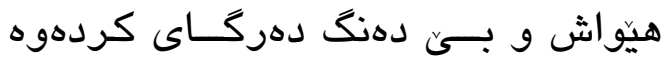

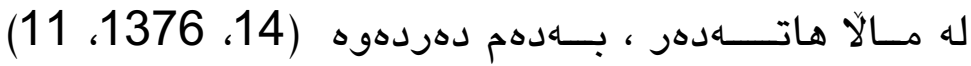

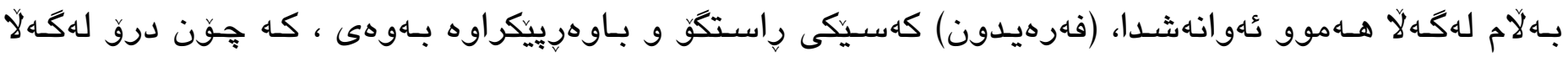

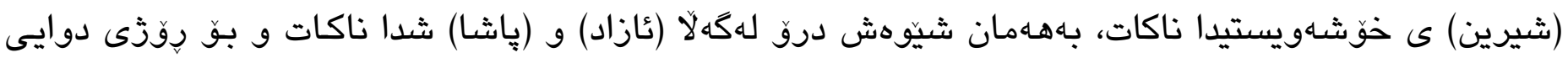

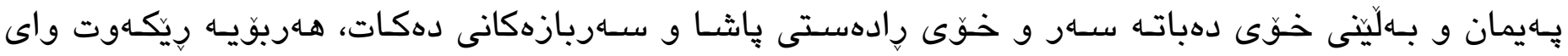

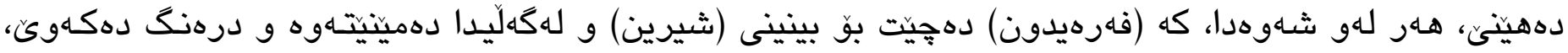

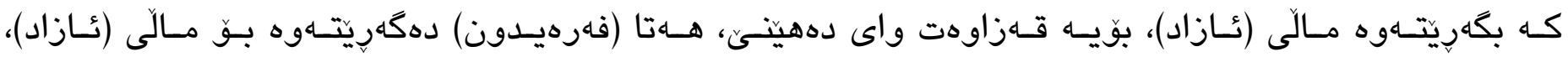

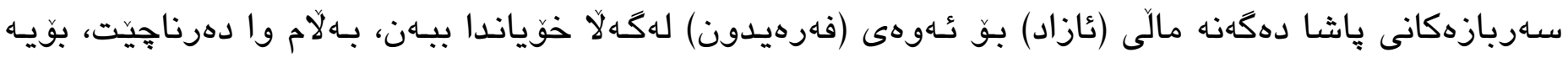

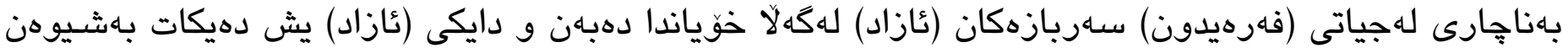

$$
\begin{aligned}
& \text { و رِقِقِ : }
\end{aligned}
$$

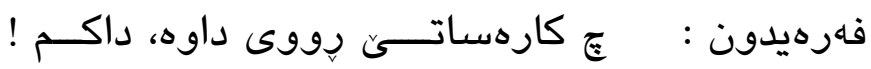

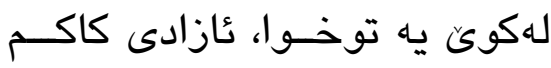

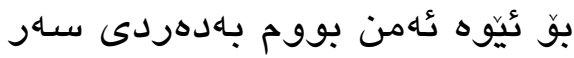

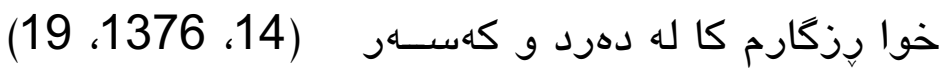

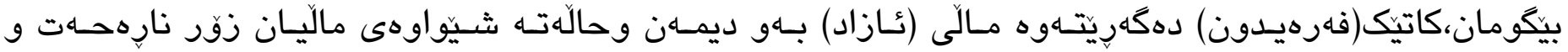

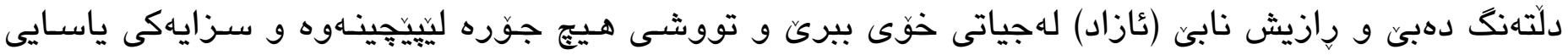




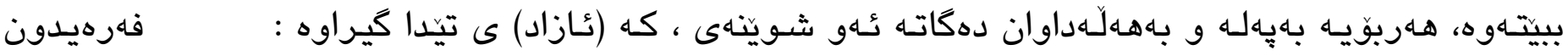
هـاهــا بـاهشين و كريان

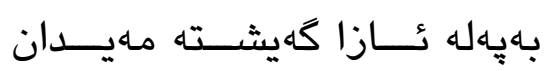

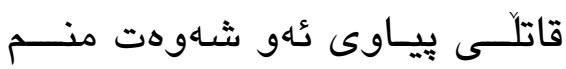

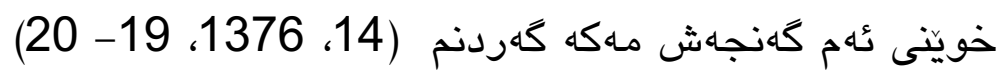

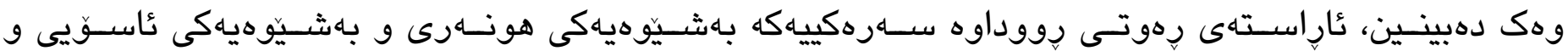

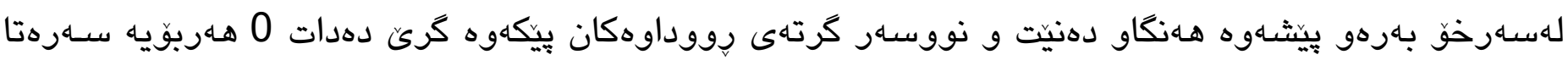

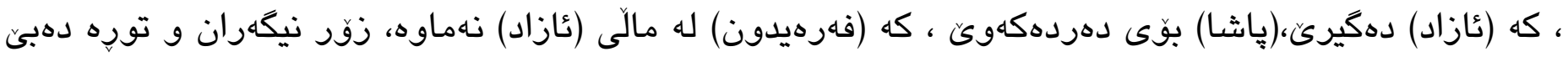

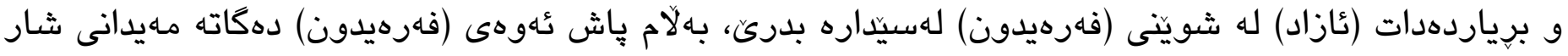

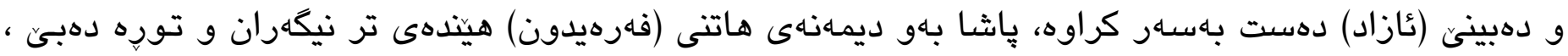

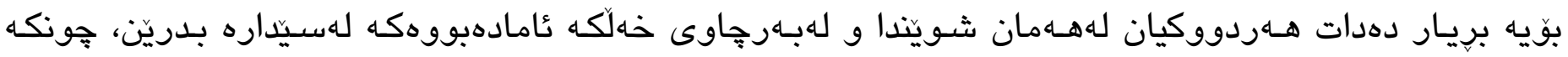

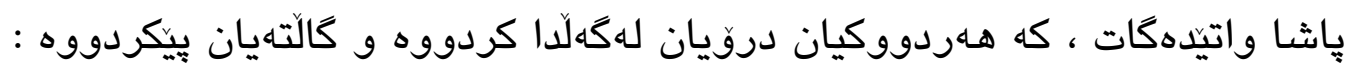

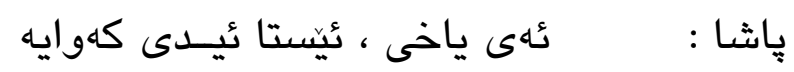

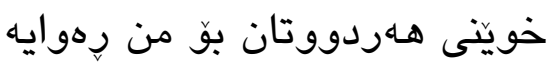

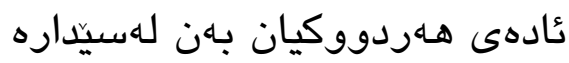

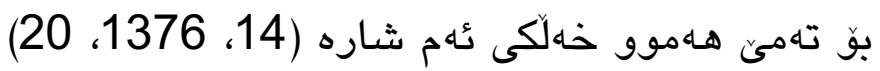

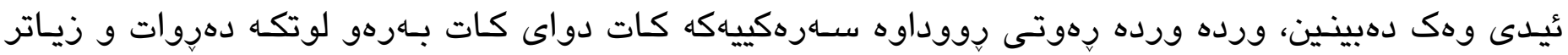

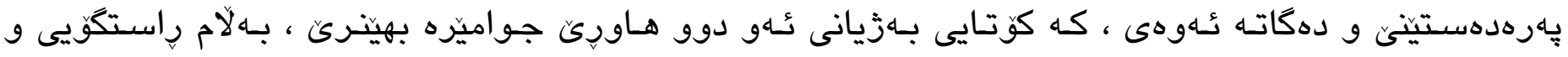

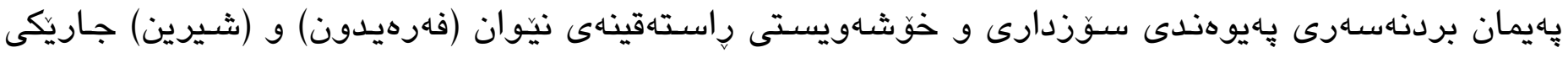

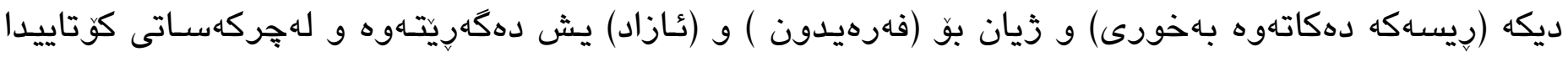

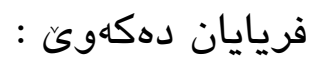

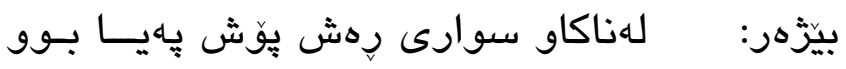

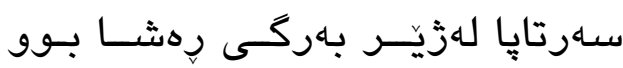

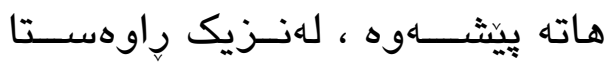

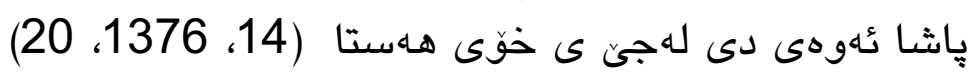

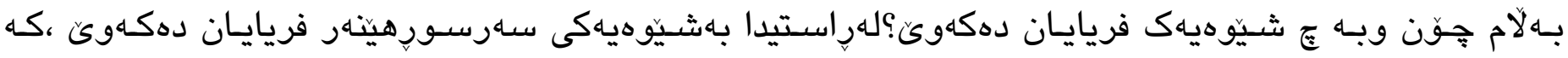

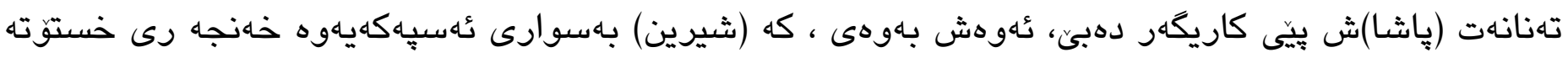

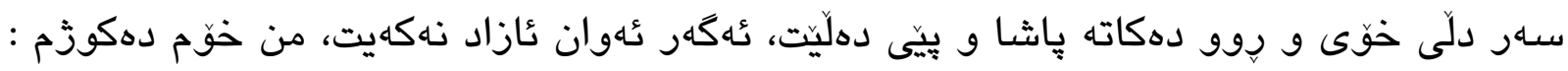

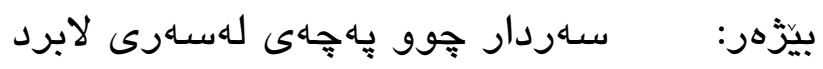

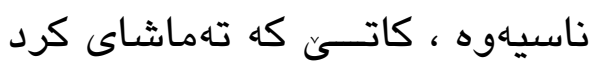

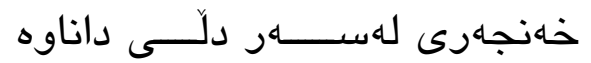

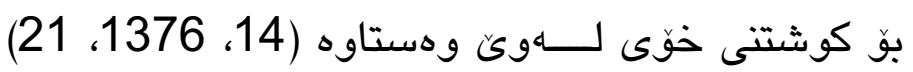

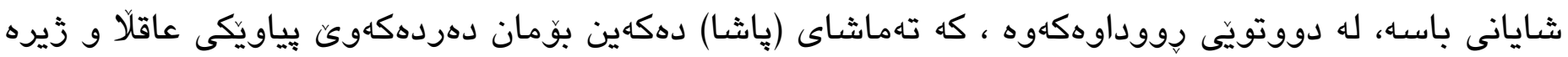

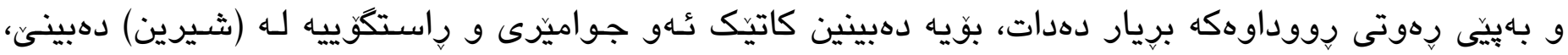




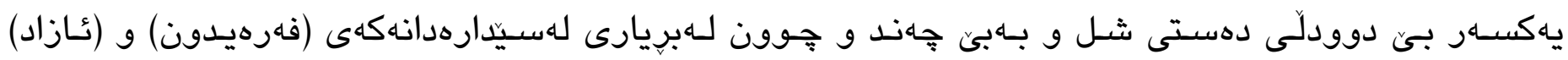

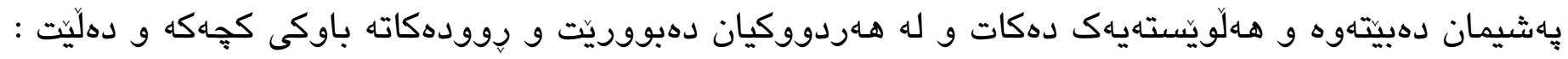

$$
\begin{aligned}
& \text { بييسه لهمن ئهى كَهـوردهى سهاردار دهار } \\
& \text { فهرماندهى سبا، ئهى بياوى هوشيار }
\end{aligned}
$$

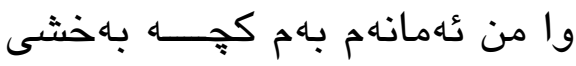

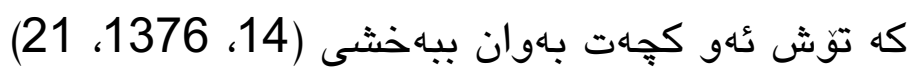

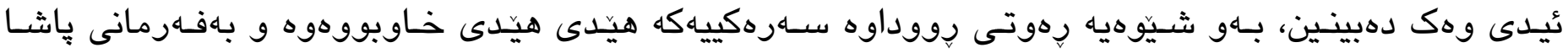

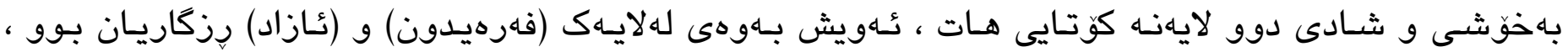

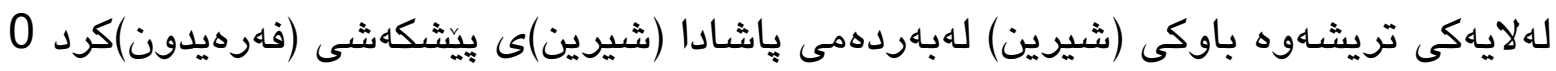

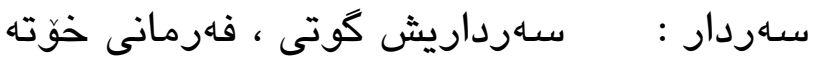

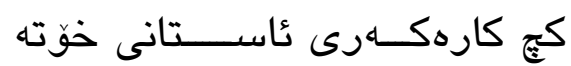

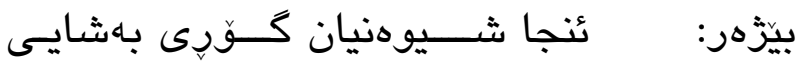

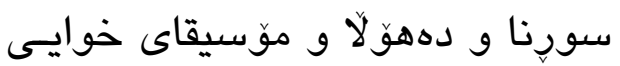

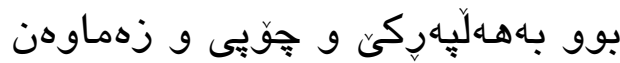

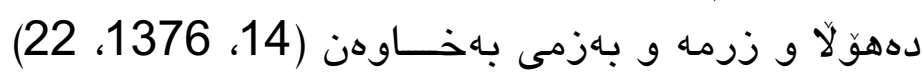

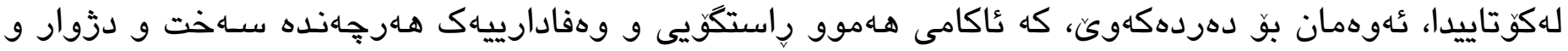

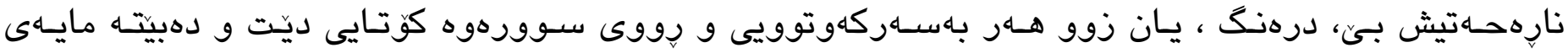

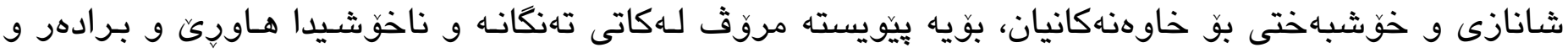

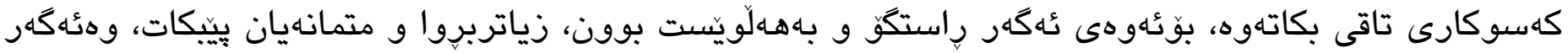

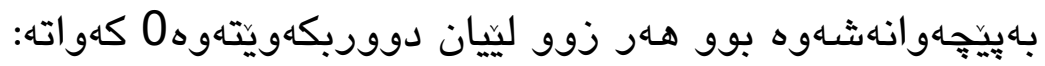

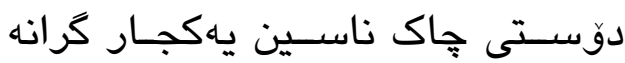

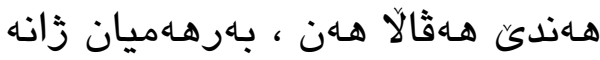

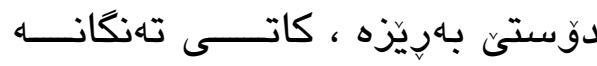

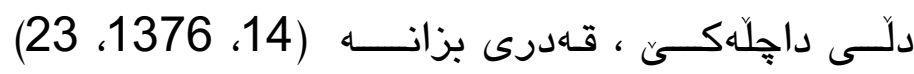

\section{2}

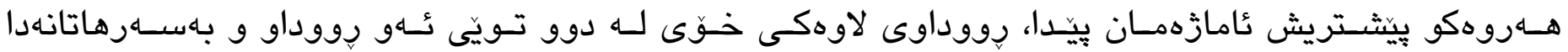

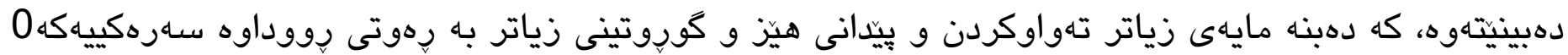

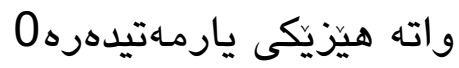

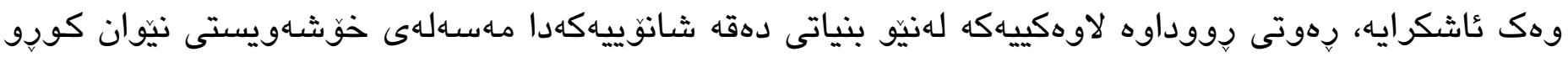

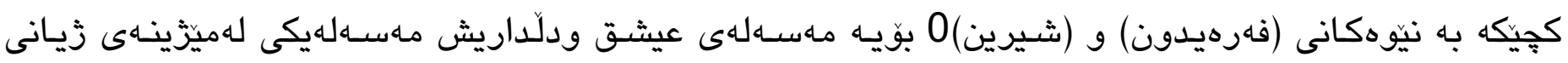

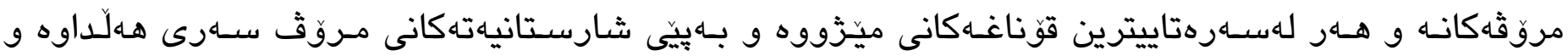

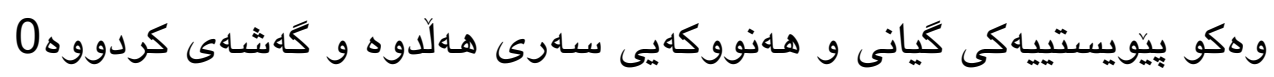




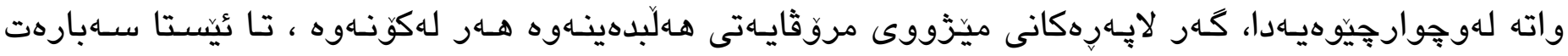

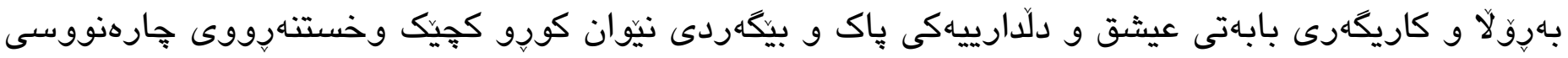

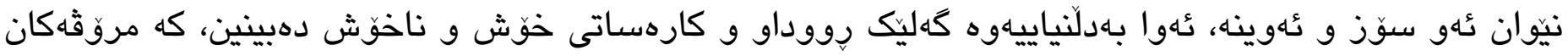

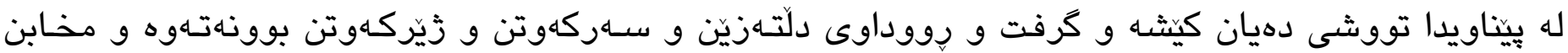

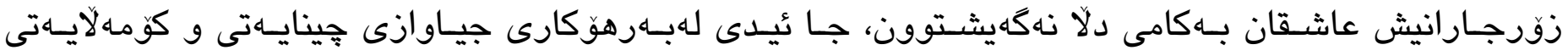

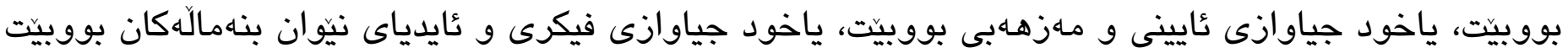

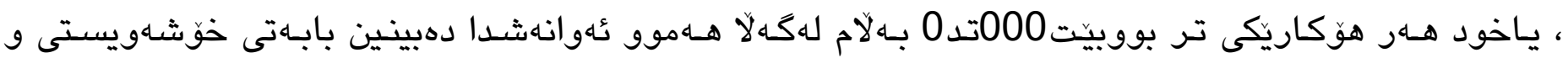

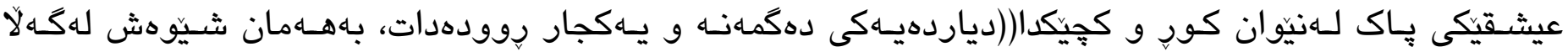

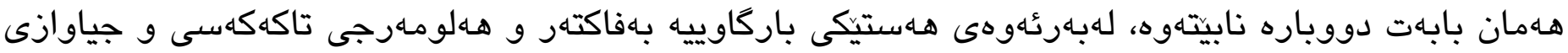

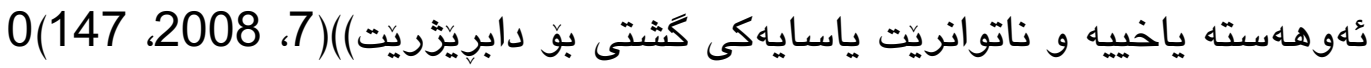

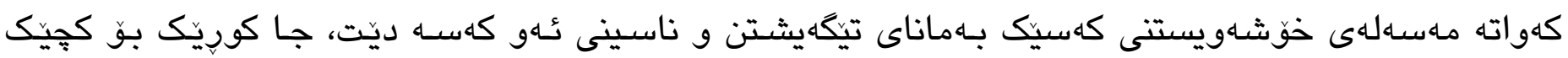

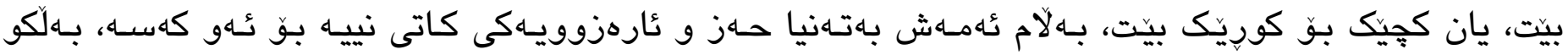

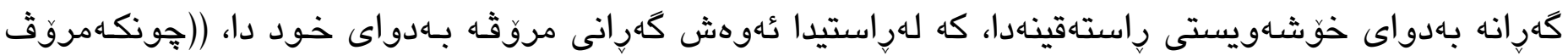

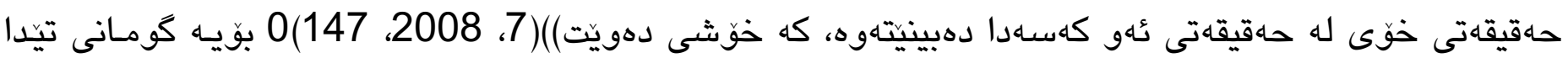

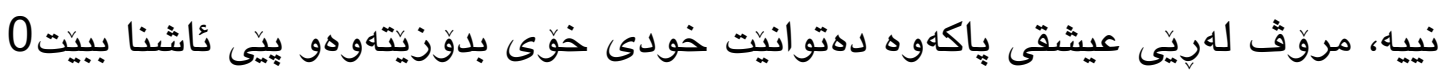

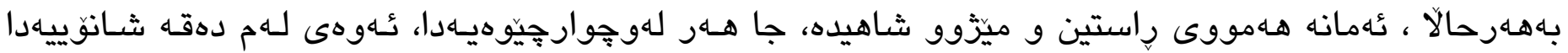

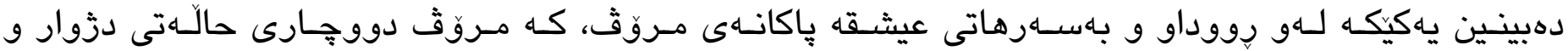

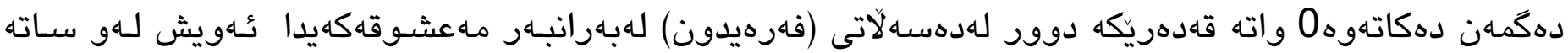

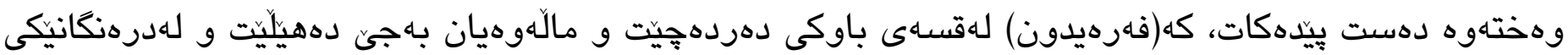

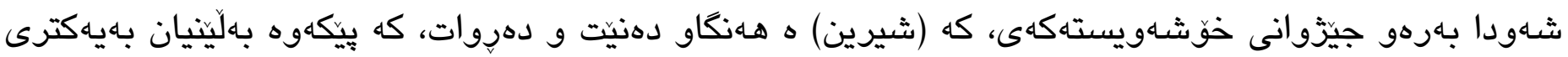

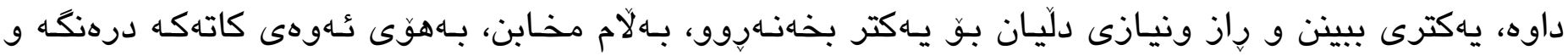

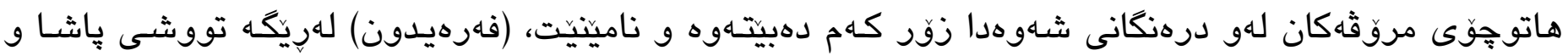

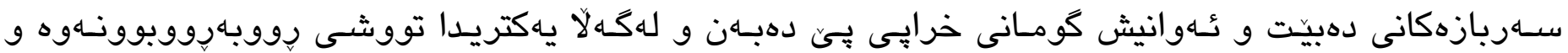

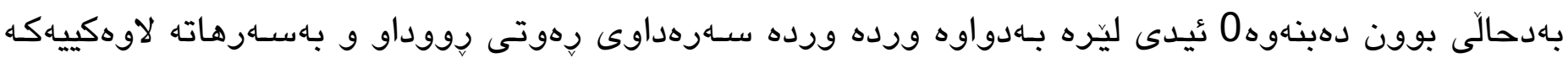
دهست پيّدهات:

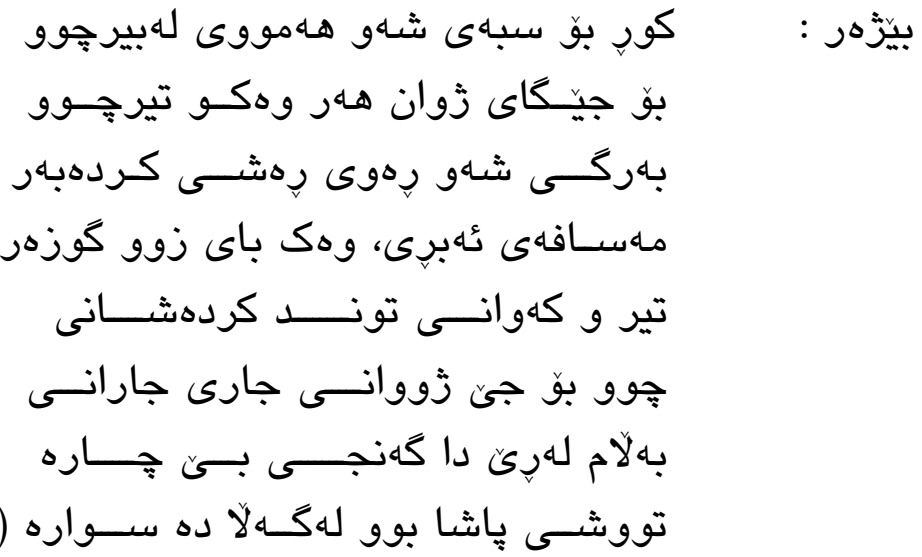




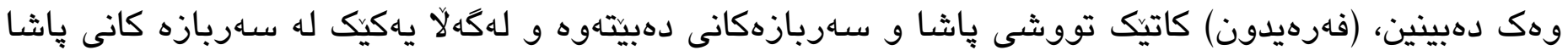

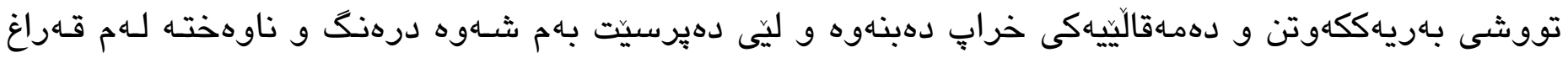

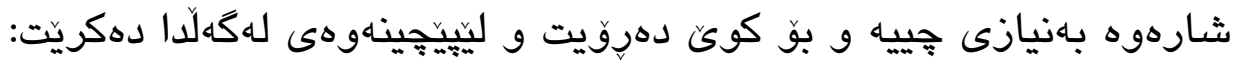

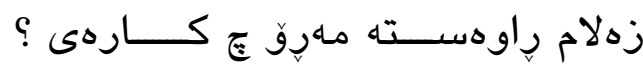

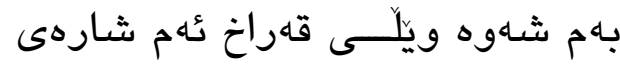

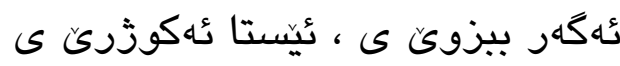

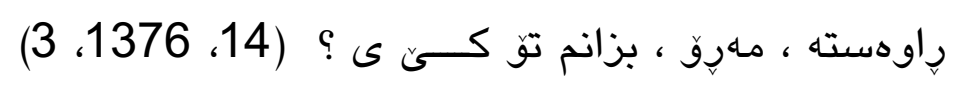

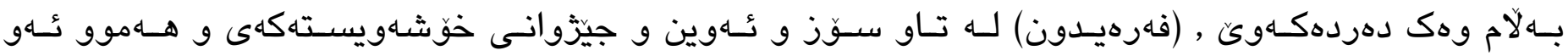

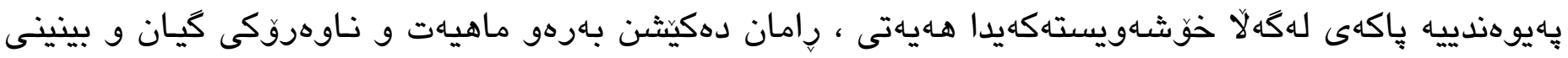

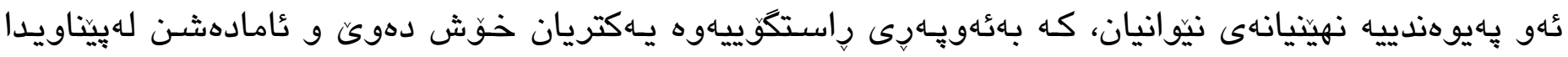

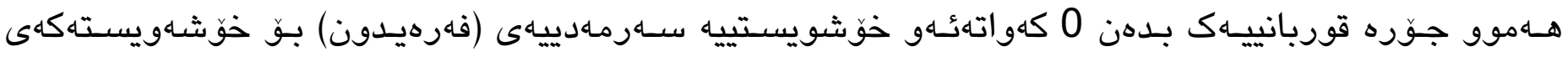

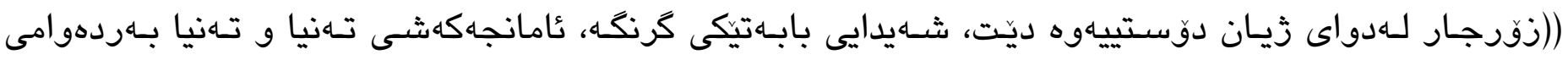

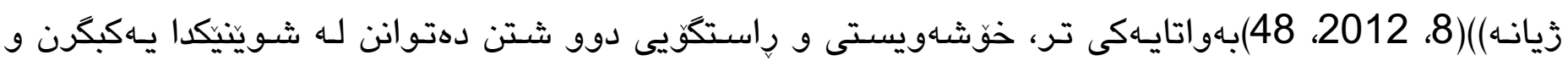

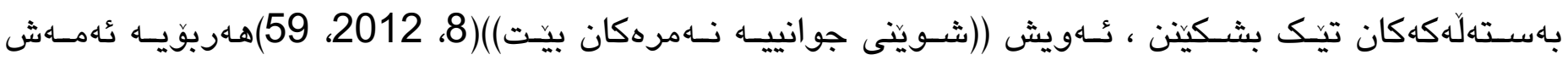

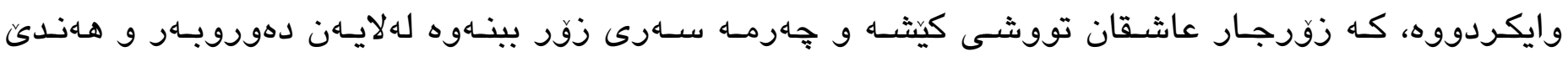

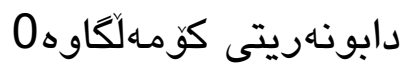

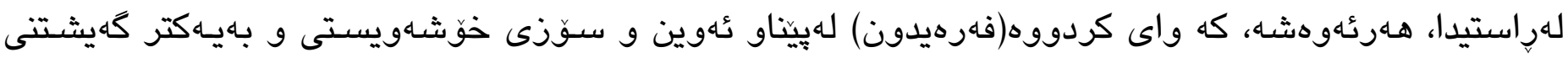

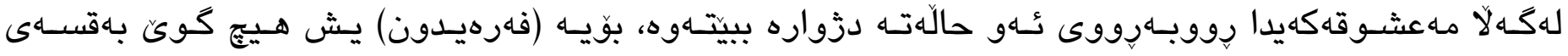

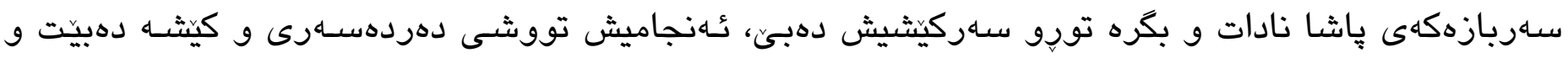

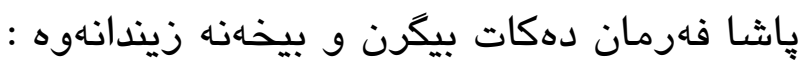

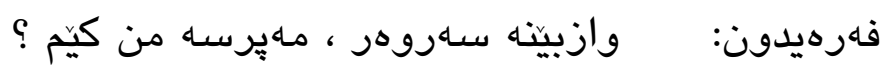

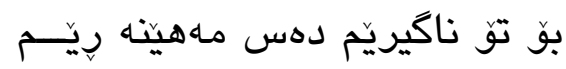

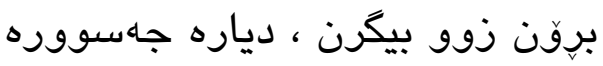
شا:

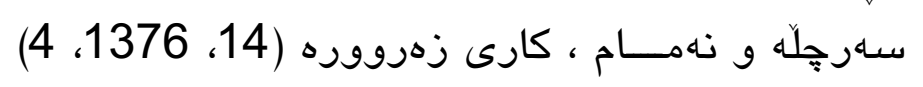

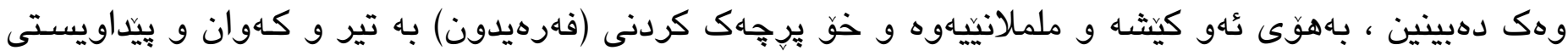

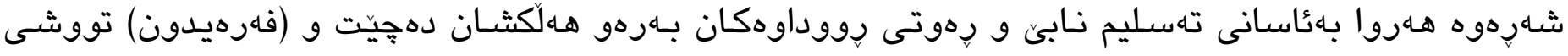

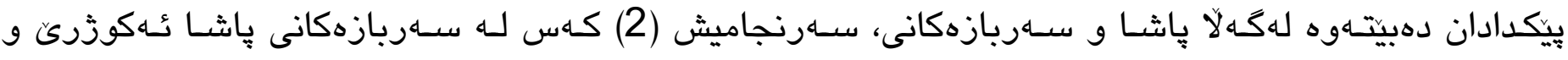

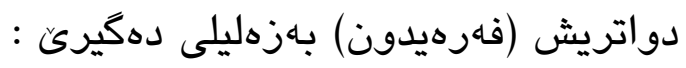

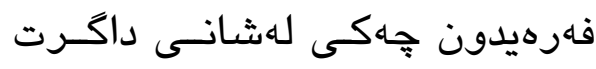

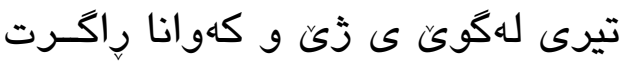

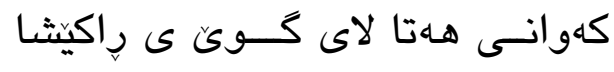

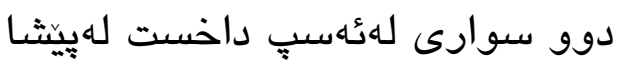

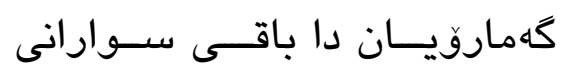
لهدهستيان وهركرت تير و كهواني لئى (14، 1376، 4) 


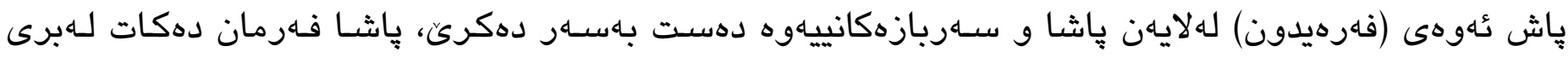

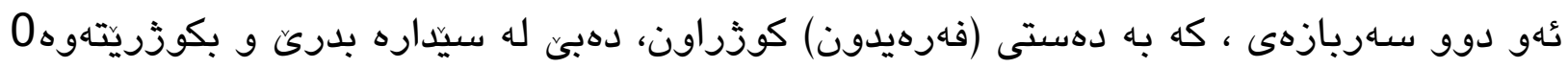

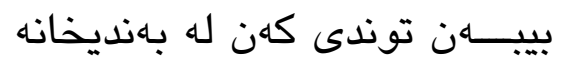

شا:

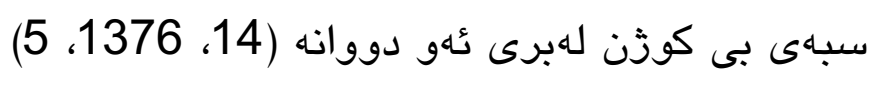

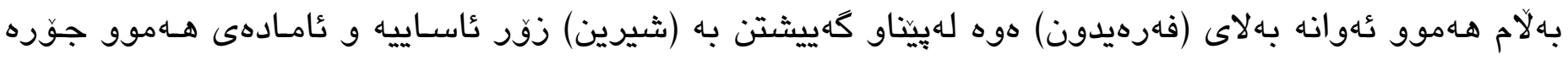

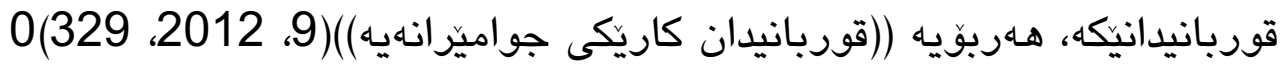

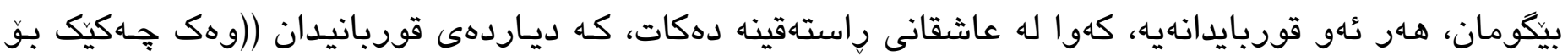

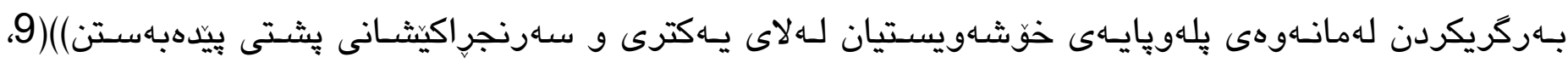

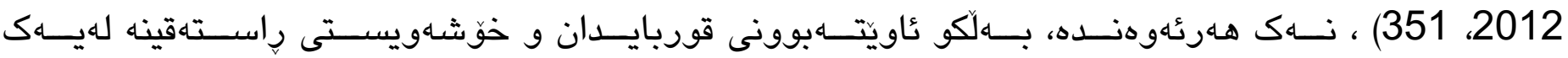

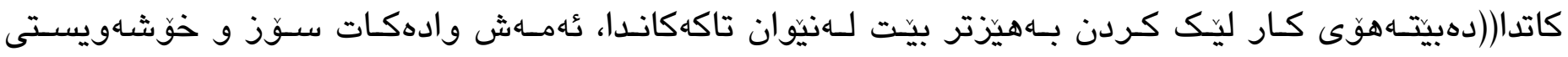

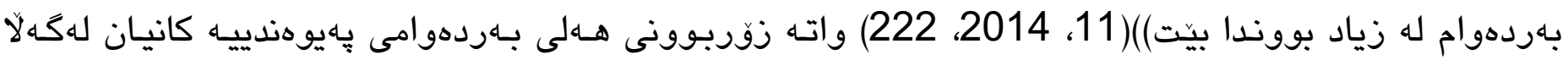
يهكتردا0

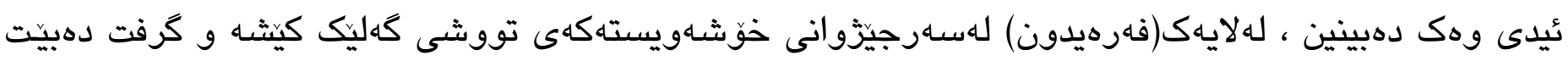

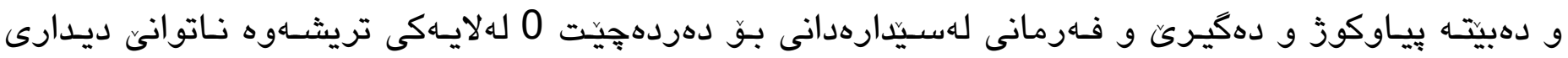

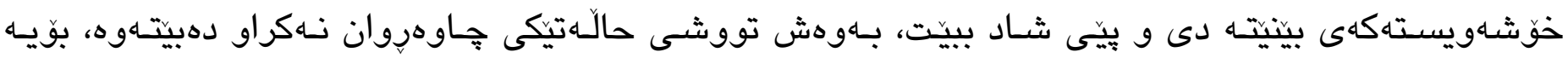

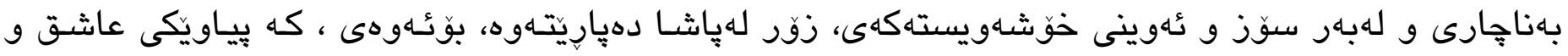

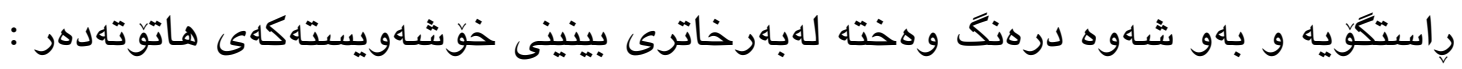

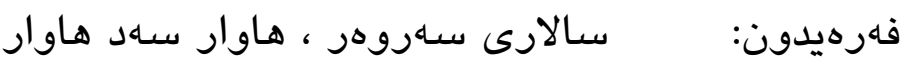

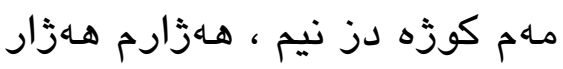

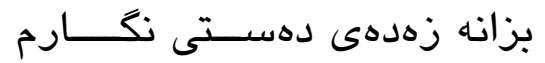

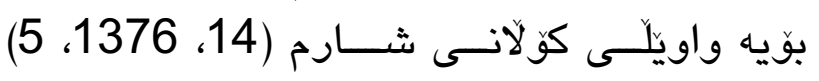

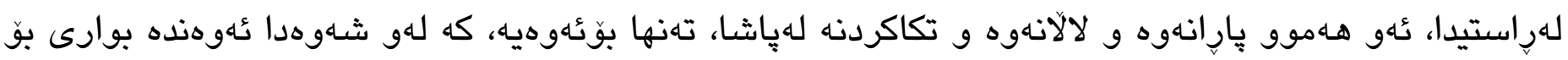

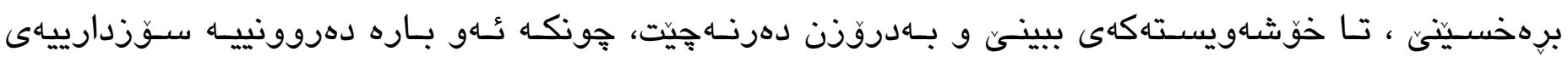

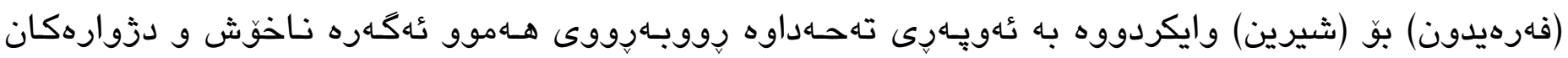

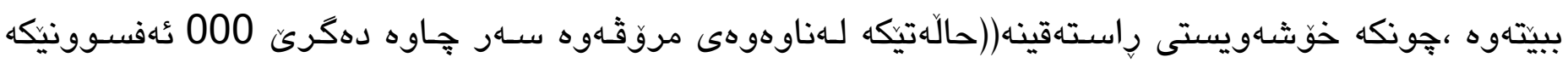

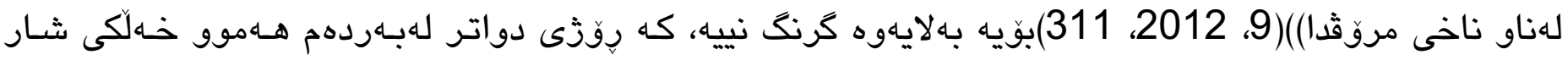

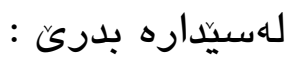

كئهمشاهو تا سبهى جويّم مـكهه له يار

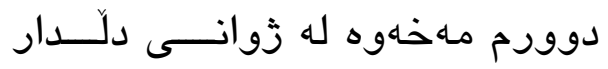

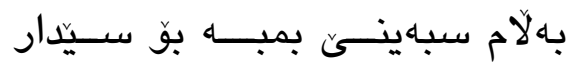

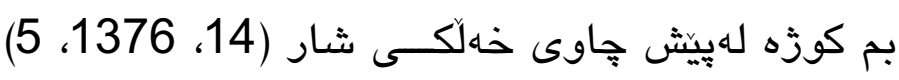

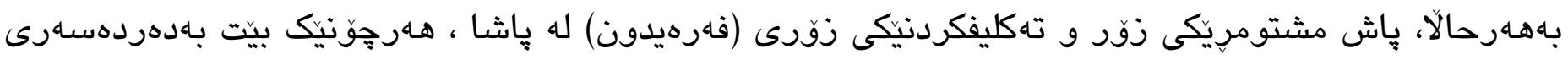

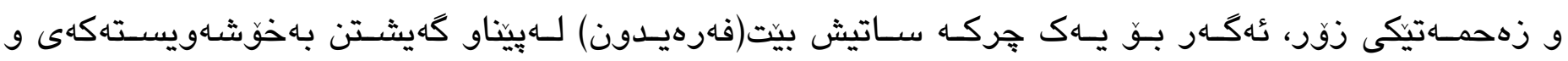

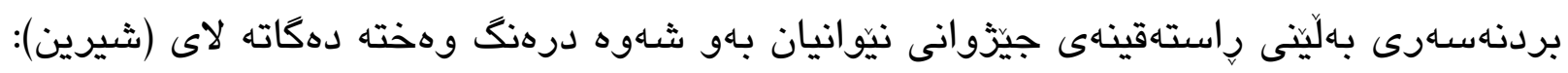

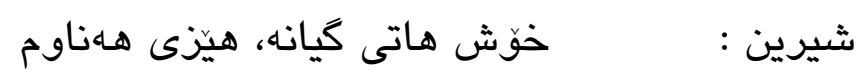




$$
\begin{aligned}
& \text { بوّ درهنگ هاتى ، رِووناكى جاوم }
\end{aligned}
$$

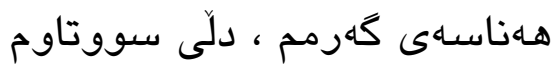

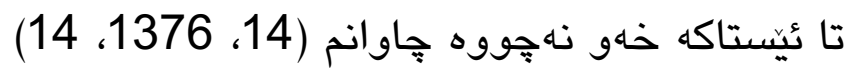

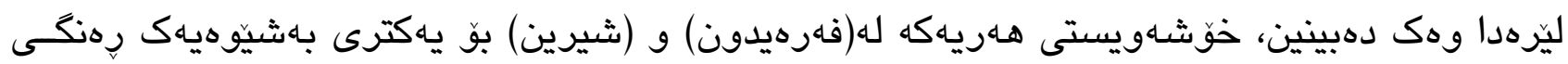

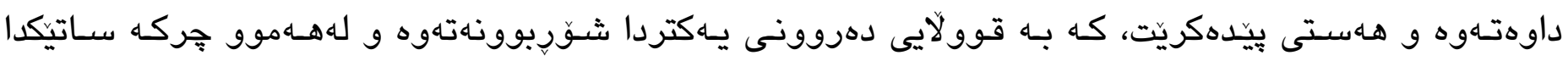

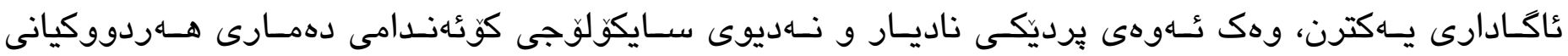

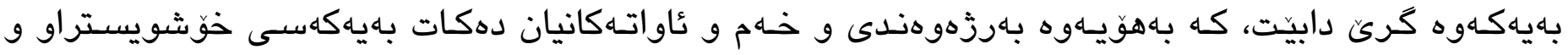

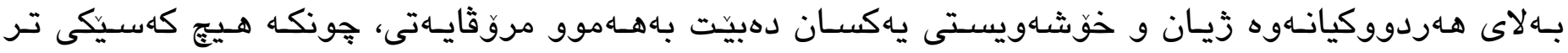

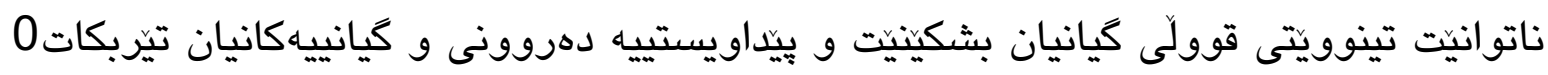

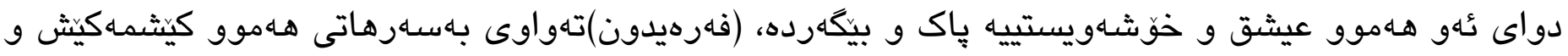

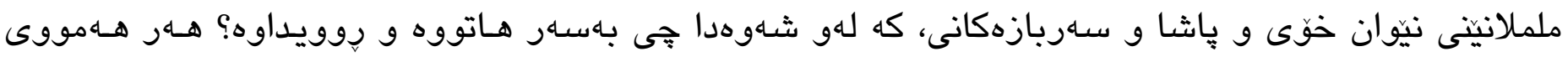

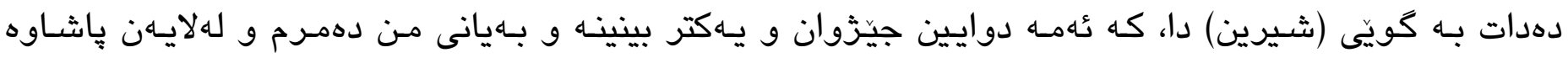

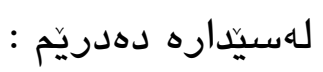

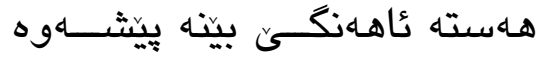

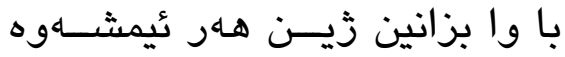

$$
\begin{aligned}
& \text { جونكه لهيهكتــر دوور ئهبيناهوه }
\end{aligned}
$$

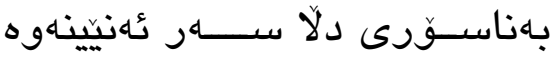

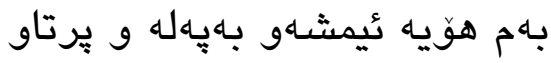

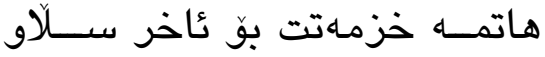

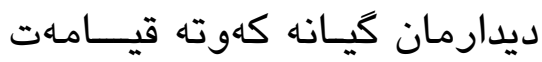

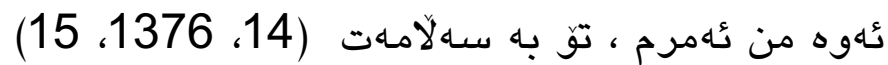
فهرهيدون:

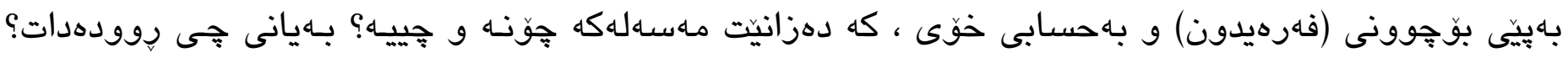

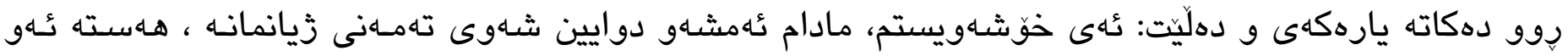

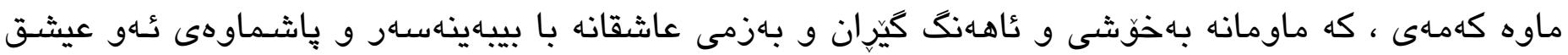

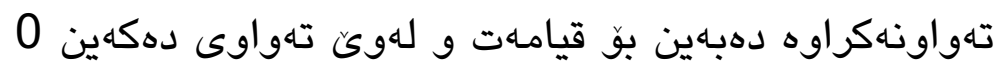

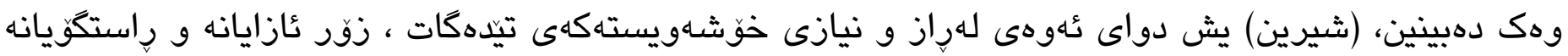

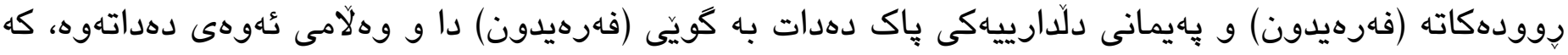

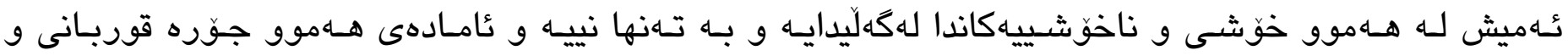

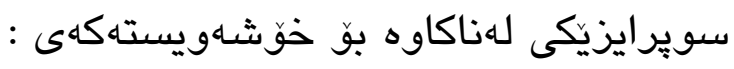

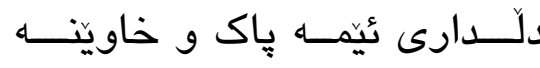
شيرين : بويراين

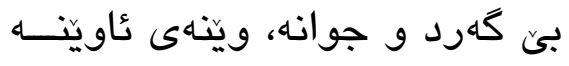

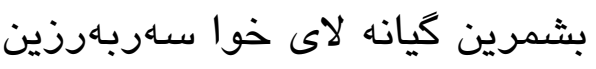

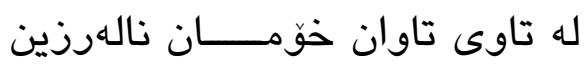

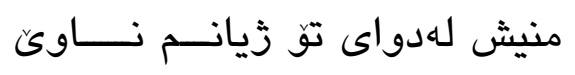

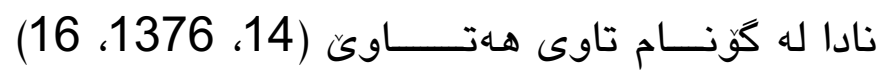




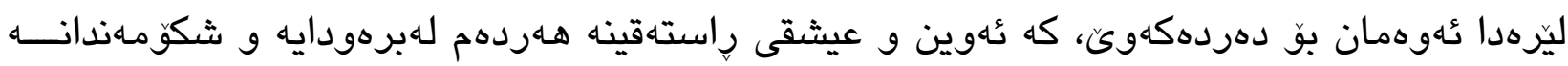

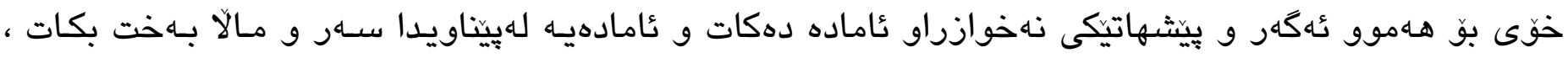

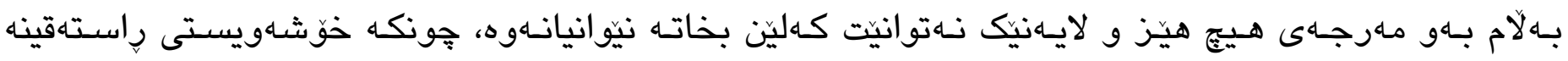

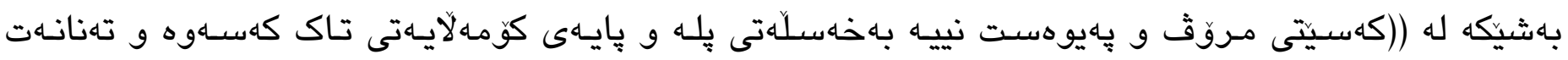

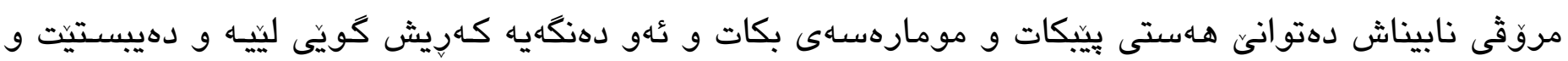

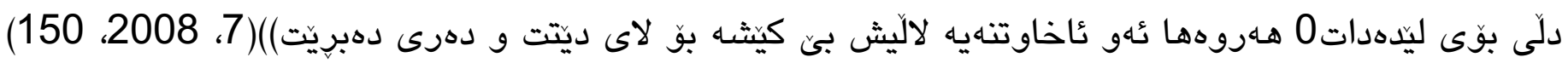

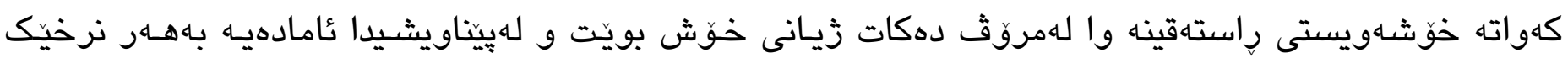

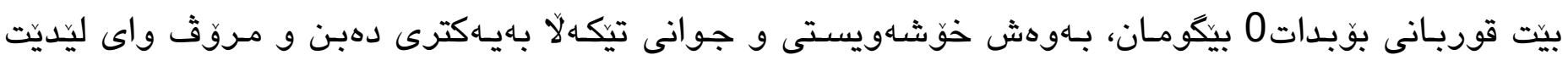

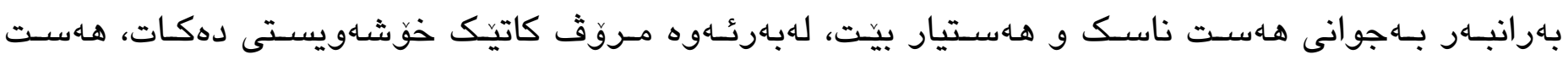

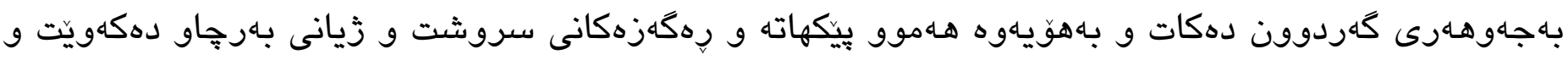

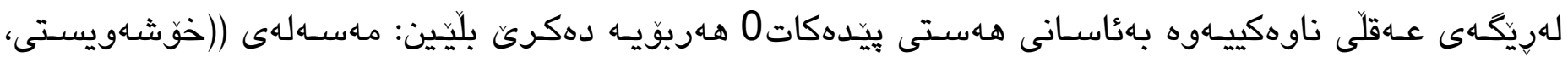

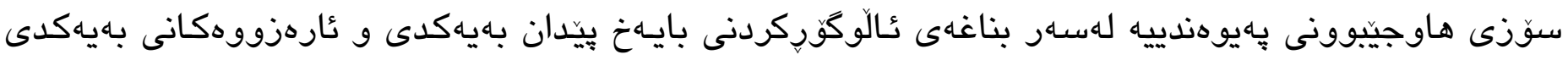

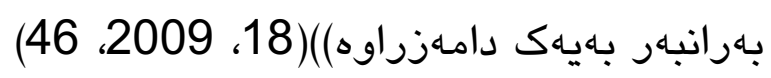

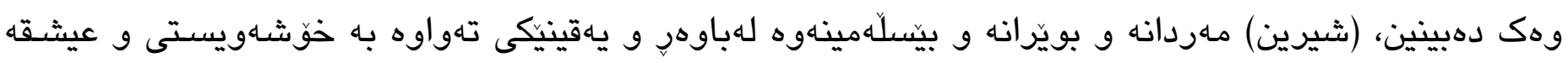

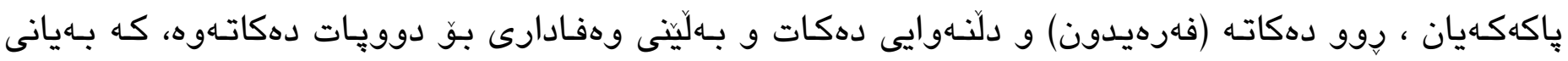

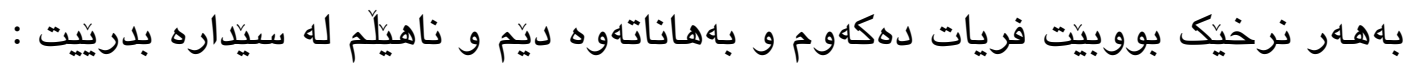

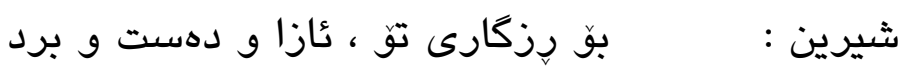

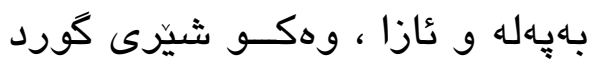

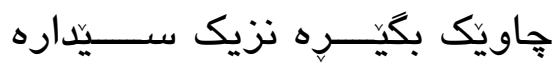

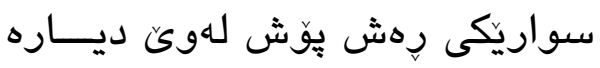

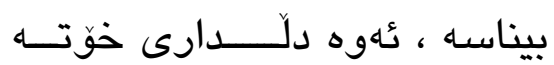

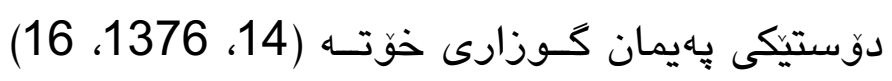

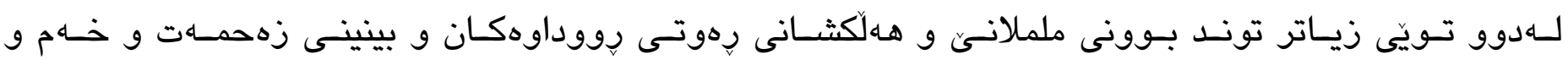

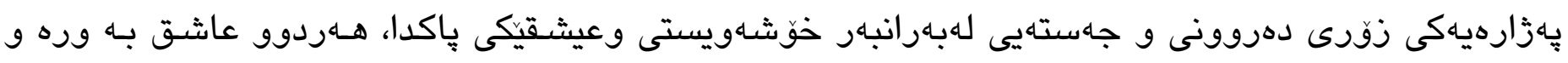

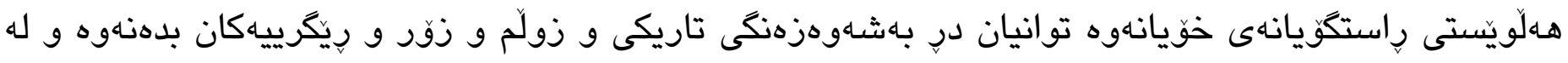

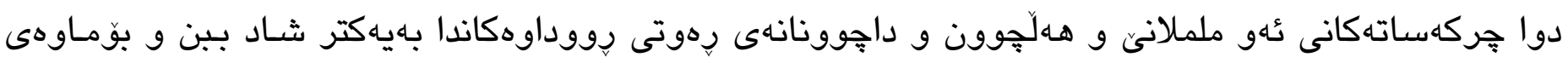

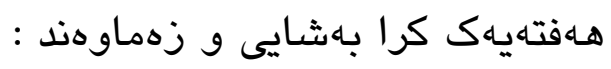

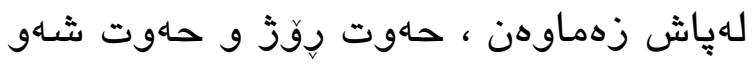

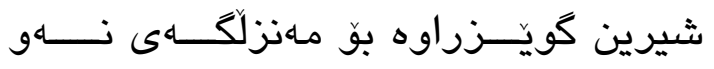

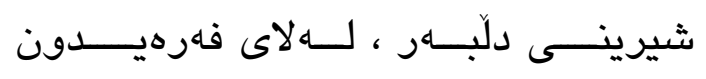

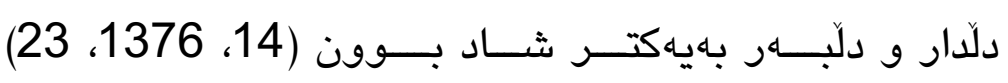

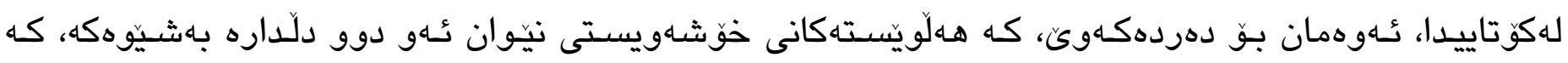

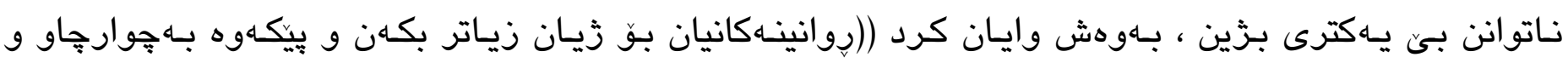

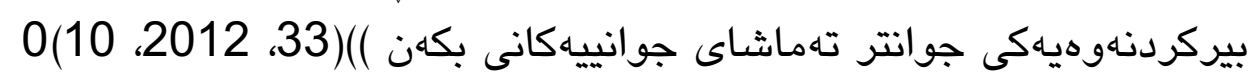




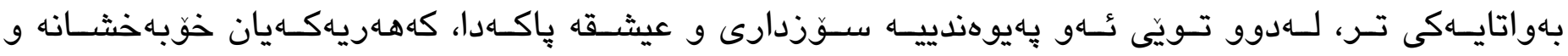

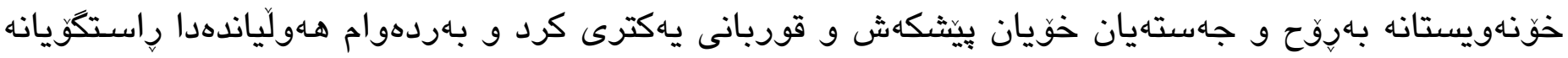

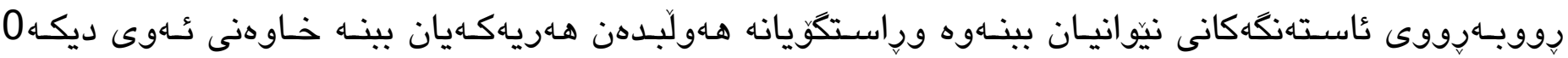

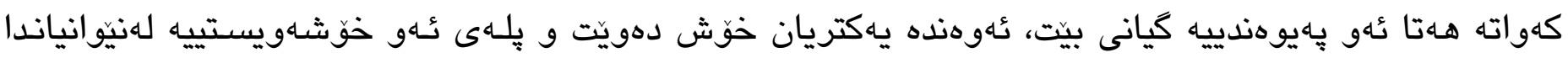
يّيكهيه 


\section{كلهنجام:}

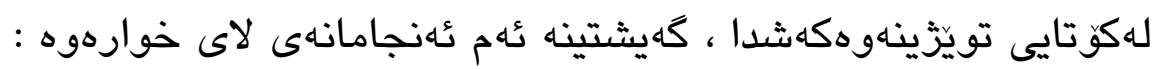

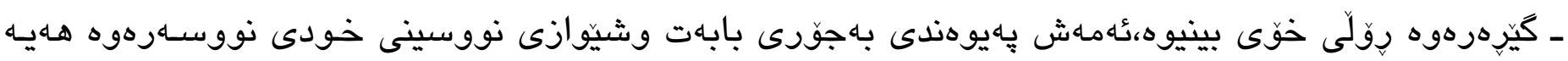

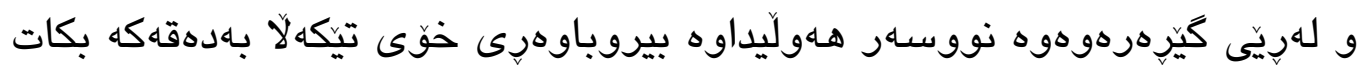

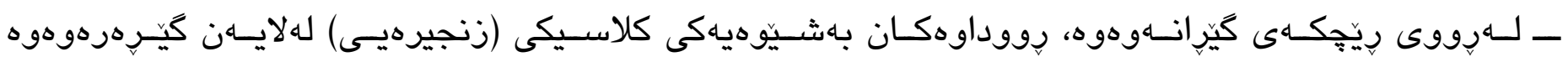

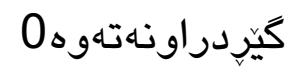

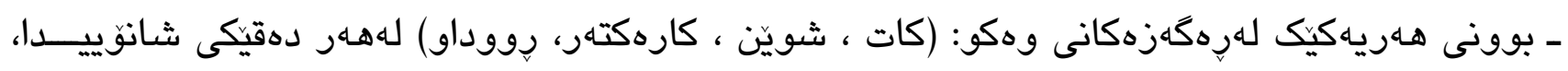

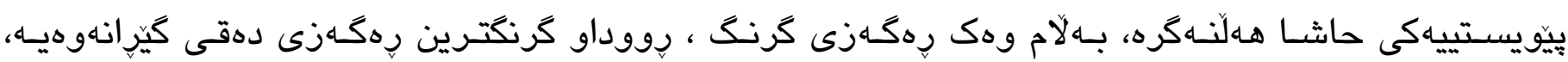

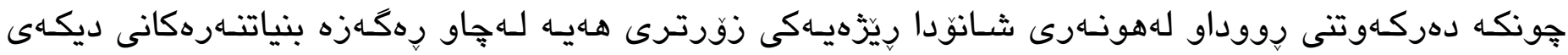

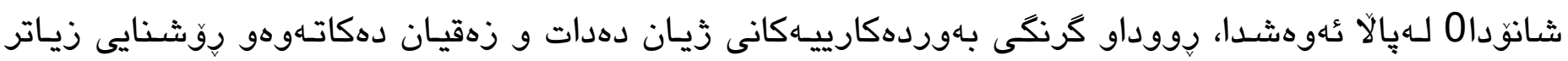

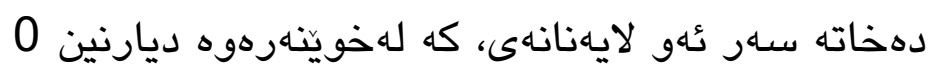

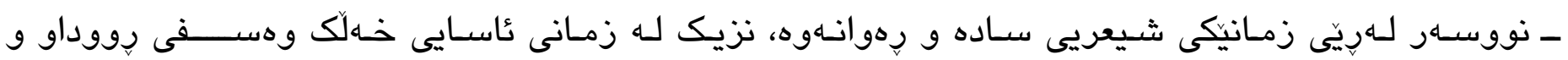

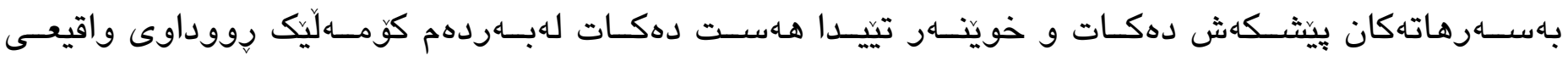

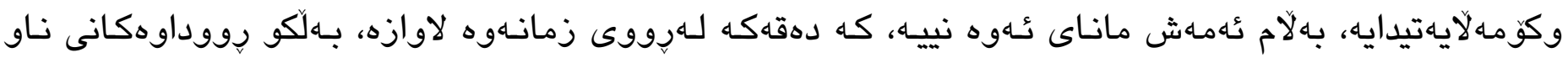

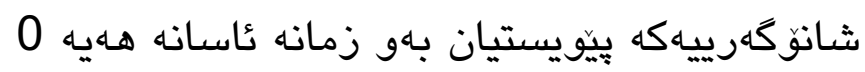

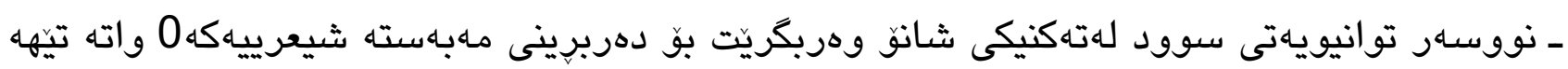

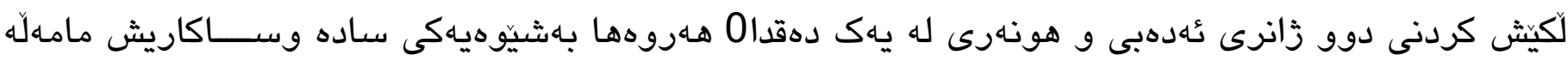

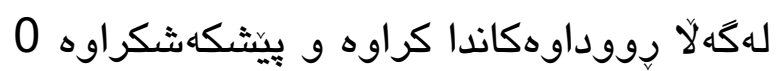

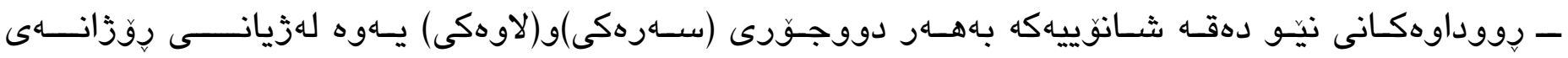

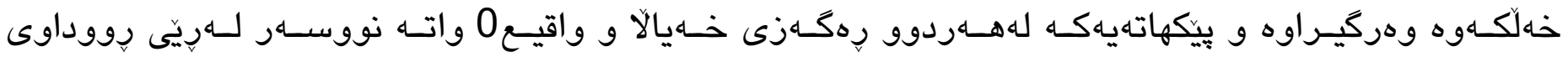

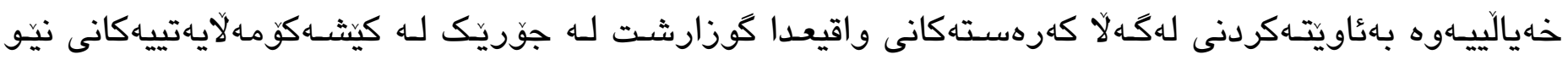

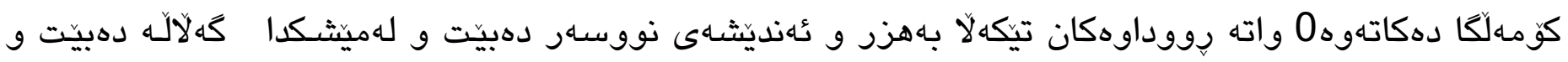

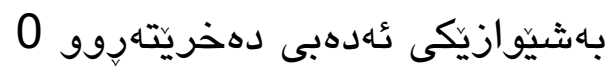




\section{سلورجاوهكان}

كثيبنيه كورديبيلكاز:

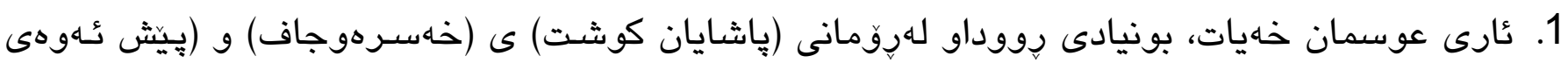

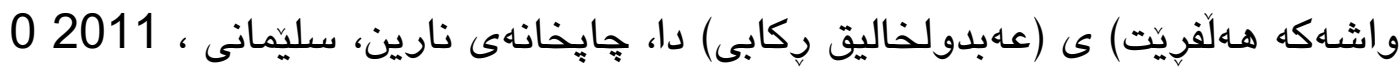

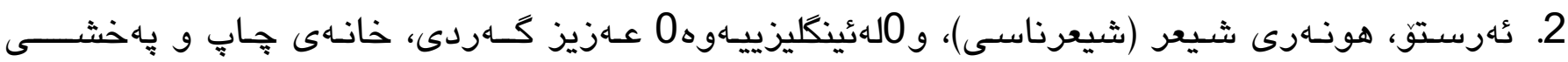
0 رِيّنما، سليّمانى ، 2004

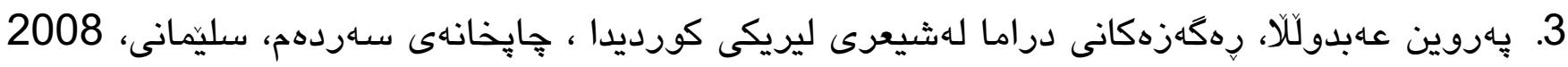

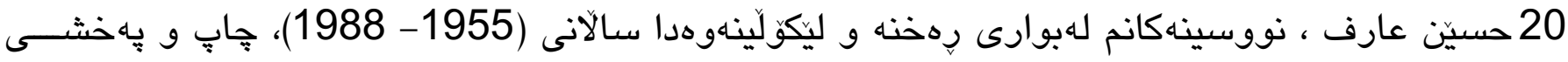

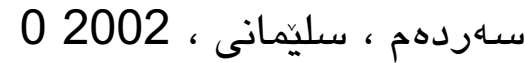

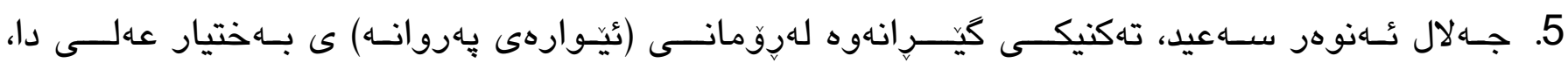

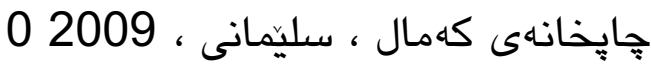

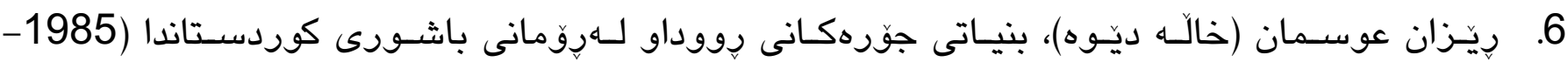

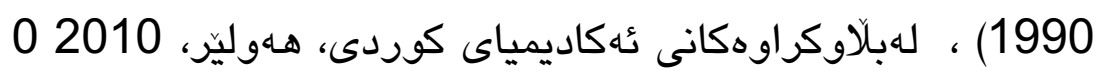

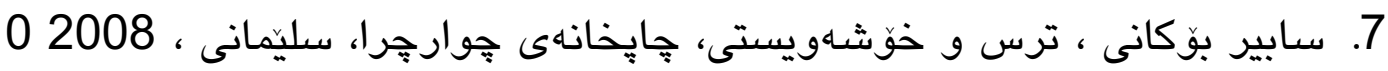

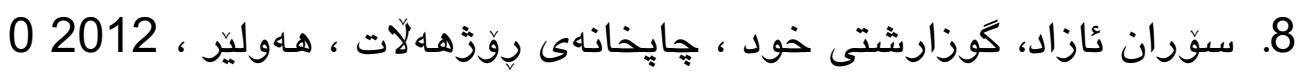

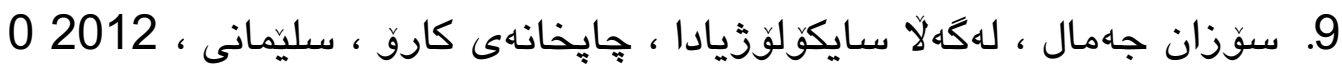

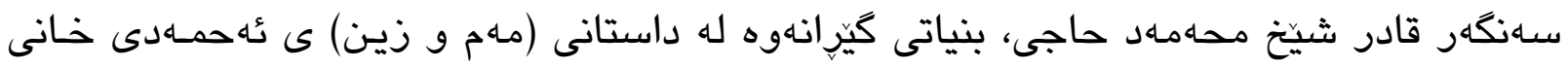

و روّمانى (شارى موّسيقاره سبييهكان) ى بهختيار عهلى دا، جايخانهى خانى ، دهوَى، 20090

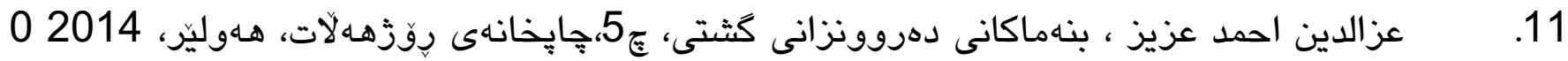
20110 .2011

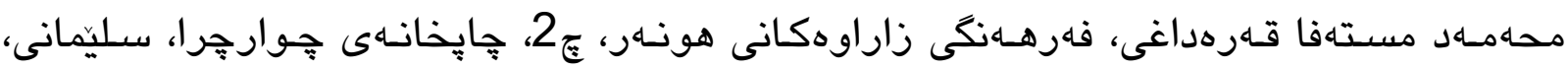

ميديا زهندى، هاثالى بهئهمـك ،ناشر: نويسنده ،سازمان انتشارات بورهكهيى، سنتدج ، 13760 .14

ميران جهلال، بنياتى رِووداو لهِّومانى كورديدا، مهلبّهندى كوردوّلوّجى ، سلينمانى ، 2009 .15

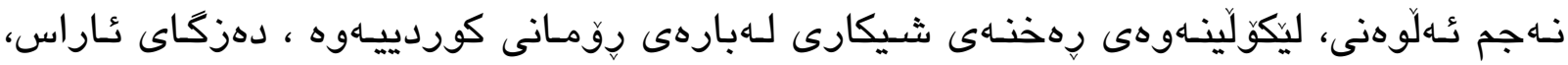

ياسين قادر بـرزنجى ، فهرهـنكى شانق، ب1 1، دهزكاى سـردهم ، سليمانى ، 2008 .17

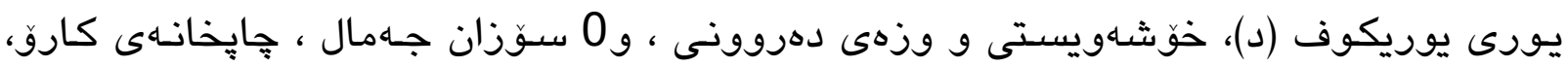




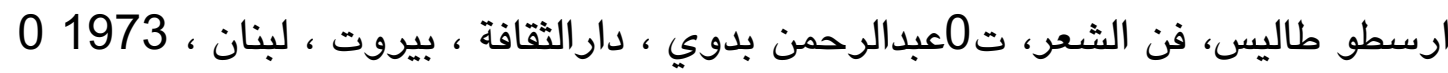

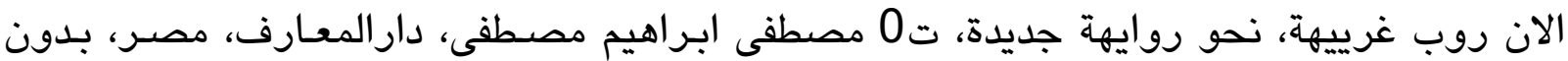

انطونيو بطرس(د)، الادب (تعريفه ، انواعه، مذاهبه)، المؤسسة الحديثة للكتاب،طرابلس ، لبنان ،

جيرالد برنس ، المصطلح السردي (معجم المصطلحات)، ت0ماعابد خزندار، الهيئة العامـة لشئون المطابع الاميرية، طال 1 ، القاهرهة ، الهات ، 2003

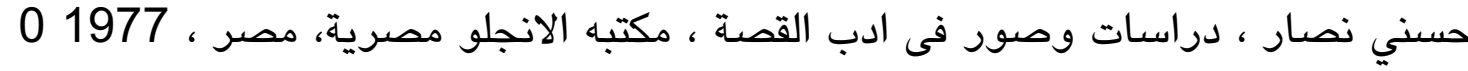

رشاد رشدى(د)، نثريه الدراما من ارسكو الى الان ، مكبعه هلا ، القاهره ، 2000 ، 200

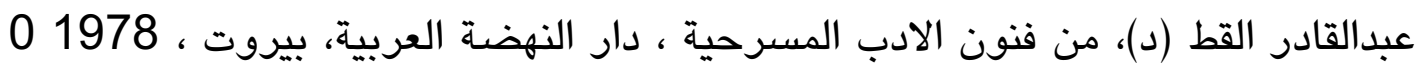

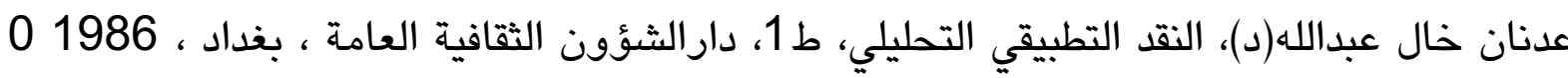

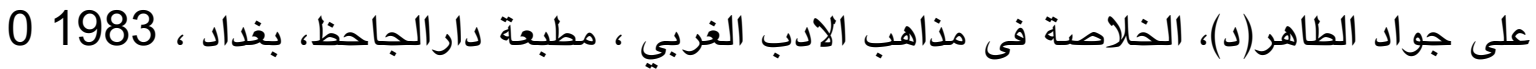

ساردار فايهق ماهيد، بنيادى رِووداو له رِومانهكانى (محمد موكرى) دا، نامهى ماستهر، كوّليجىى

0 زمان ، زانكوى سليمانى ، 2013 ياسين رهشيد حهسهن، ناوهروك و تهكنيكى درامساى كوردى (1991- 2002)، نامسهى ماستهر، 


\section{ملغص البعث:}

يعد الحدث سلسـله مـن الوقائع المتصـله التى تتسـم بالوحده والدلاله، اي نقام نسـقى مـن الافعـال، وهـو الطريقة

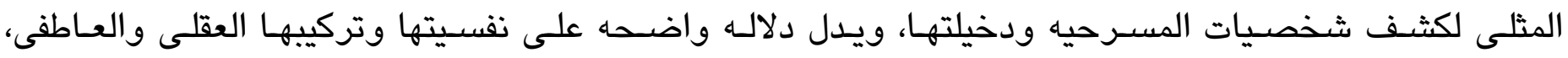

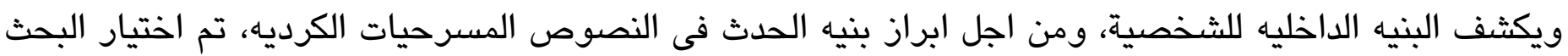

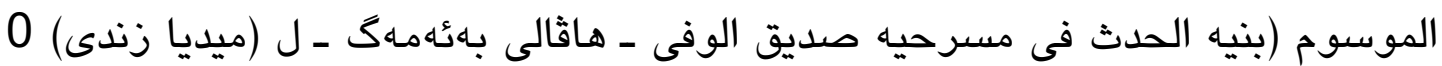
واثر البحث ان يكون فى فصلين، وقد خصص الفصل الاول المتكون من ثلاث مباحث للجانب النظرى، فى البحث الاول تناول تعريف الحدث، وفى المبحث الثاني اهميـه الحدث وعلى وجـه الخصـوص فى النصـوص المسـرحيهة، وفى المبحث الثالث تتاول انواع الحدث، وخصص الفصل الثاني للجانب التطبيقي لتحديد وعرتج نمازّج مـن الاحداب الفرعية والرئيسيه فى المسرحيه وفى الختام استعرض البحث اهم النتائج التى توصـل اليها البحث، ومنها ان المؤلف يحساول وعن طريق الراوى ويشكل متسلسل التطرق وعرض اراوه وافكاره فى المسرحيه، وعن طريق العناصر الاخرى كالشخصية والثية والزمان

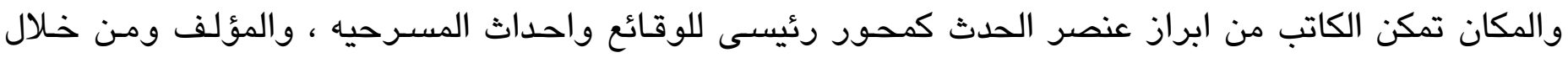

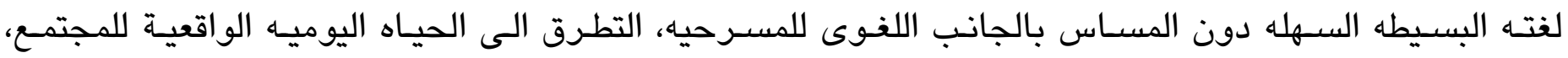

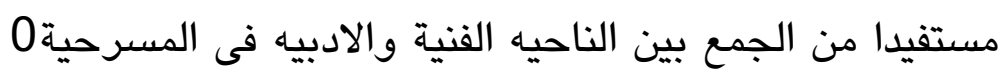
واخيرا عرض قائمه باهم المصادر والمراجع التى استفاد منها البحث، مع ملخصين باللغه العربيه والانكليزيه 
Abstract:

This paper gives a detailed introduction to create the structure of event. Finally, We :can conclude the following points Narration is an important point of this play, in other words ,narrator's role to practite the style of the writer and her ideology in this text

.(The techniques of Narration clarify all events as a classical style (seriesThe elements of the text are (time, location , characters, event,...).It is well known that event of text is the most important element to create an artistic play. In addition, the event simplifies the hidden points of the play and life The writer narrates serial events using a simple poetic language to convince the readers about social and real events. This is not a weak point of this play but the simple language is necessity of this text The dramatist (writer) could use the technique of drama to express her poetie aim .(i.e Literary and Artistic) elements in the same text (play The events of plot in this text, both sides (main events and secondary events)are quoted from people's daily life mixing realism and imagination. In this way, the dramatist uses a real poetic style to express

Social problems in society,it means all elements have been accomplished in .dramatist's mentality and her imagination as a literary style and fantastic text 